\title{
Effect of Planting Dates and Fertilization on Yield and Yield Components of Onion (Allium cepa L.) Grown from Sets Mohamed, A. G. ${ }^{1}$; A. M. El-Damarany ${ }^{2}$ and R. A. Marey ${ }^{1}$ \\ ${ }^{1}$ Onion Res. Depart. , Field Crops Research Institute, Agric. Res. Center, Giza, Egypt \\ ${ }^{2}$ Vegetable Crops Depart., Fac. Agriculture, Sohag Univ., Egypt
}

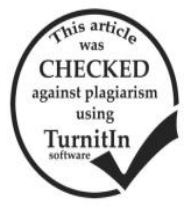

\section{ABSTRACT}

This study was conducted during the two growing seasons of 2013/2014 and 2014/2015 to investigate the effect of planting dates $\left(15^{\text {th }}\right.$ August, $1^{\text {st }}$ September and $15^{\text {th }}$ September), NPK treatments (Control; 50, 15, $12 \mathrm{~kg} / \mathrm{fed} \mathrm{NPK} ; 75,30,24 \mathrm{~kg} / \mathrm{fed}$ NPK and $100,45,36 \mathrm{~kg} / \mathrm{fed} \mathrm{NPK}$ ) and spraying with micronutrients (Control, spraying once and spraying twice) on onion productivity. The obtained results could be summarized as follow: 1- Planting on $15^{\text {th }}$ September significantly increased plant height, number of leaves/plant, plant fresh weight, plant dry weight, total bulbs yield, bolters $\%$ and double bulbs $\%$, in both seasons. 2- Application of the highest rates of NPK appeared significant higher records for plant height, number of leaves/plant, plant fresh weight, plant dry weight, total bulbs yield, bolters $\%$ and double bulbs $\%$, while the control treatment appeared the lowest of these traits in both seasons. 3- Means of plant height, number of leaves/plant, plant fresh weight, plant dry weight and total bulbs yield were significantly increased by increasing times of spraying with micronutrients, while the control treatment gave the lowest values, in both seasons. It could be recommended that planting on $15^{\text {th }}$ September, fertilizing with of $100+45+36 \mathrm{NPK} \mathrm{kg} / \mathrm{fed}$. and spraying twice with microelements to achive maximum yield and yield components.

Keywords: Onion set, Planting date, NPK, mictonutrients.

\section{INTRODUCTION}

Onion (Allium cepa, L.) is one of the most important vegetable crops in Egypt for consumption, processing and exportation. Dry onion sets can be used for onion planting to attain the advantage of early maturity and escaping from white rot disease. Such method of planting is also promising for the possibly of exportation and for the dehydration industry as well (Baghdady, 2008). Great attention should be paid to improve sets planting method and to study the factors which affect the plants and their characters during the vegetative (Abd El-Fattah et al., 1983).

Planting date for onion set reflecting the effect of edaphic factors and all environmental conditions on growth, bulb yield and bulb quality. It was found that planting date, temperatures and photoperiod represented the main factors which affected the productivity and quality of onion bulbs, so the choice of the optimum planting date for each region is very important. Farghali et al. (1991) pointed out that when planting onion sets was done on August 15 earliness was insignificant comparing planting that was done later. Planting sets in early as $15^{\text {th }}$ August gave the lowest total bulb yield, however, later planting on September $1^{\text {st }}$ and $16^{\text {th }}$ September gave higher average bolter\% than those did of August 15 planting. Singh and Singh (2003) reported that the early date of planting (21 August) of sets resulted in the maximum marketable bulb yield compared with the September planting. Sharma et al. (2003) reported that planting on $15^{\text {th }}$ August recorded the greatest bulb diameter, bulb weight, plant height, and average bulb yield.

The primary macro elements of nitrogen, phosphorus and potassium (NPK) are very important for plant growth, maturity, bulb yield and bulb quality. The application of NPK fertilization in a balance ratio is prerequisite for producing high yield of onion bulbs with a good keeping quality. Nitrogen is an integral part of chlorophyll. It is essential for synthesis of proteins and enzymes. Phosphorus and potassium play a vital role in several keys of physiological processes viz. photosynthesis, respiration, energy storage (ATP, ADP formation), and enhancing the translocation of assimilates and protein synthesis (Marschner, 1995, El-Desuki et al., 2006 a \& b). Onion plant is sensitive to nutritional balance, as the result for its shallow root system and its high productivity, also it cosedred a long term crop (Yaso et al., 2007).

Micronutrients are needed by the plants in a minor quantities and present in plant tissue in quantities measured in parts per million, but it is involved in a wide variety of metabolic processes and cellular functions within the plants. Also, they work as a co-enzyme for a large number of enzymes. In addition, they play an essential role in improving yield and quality, and highly required for better plant growth and yield of many crops (Barker and Pilbeam, 2007 and Hänsch and Mendel, 2009). Foliar spraying with micronutrients appeared a consedrable success in Egypt for several crops in the Nile valley, the Nile Delta and the adjacent reclaimed soils (Ghoname et al., 2007).

Therefore, the objective of this investigation was to study the effect of planting date, NPK fertilization rates and spraying with micronutrients on plant growth, yield and its components and bulbs quality of onion grown from sets.

\section{MATERIALS AND METHODS}

This experiment was carried out in the two seasons of 2013/2014 and 2014/2015. The treatments of the experiment were arranged in a split-split plot design with three replicates. Planting dates $\left(15^{\text {th }}\right.$ August, $1^{\text {st }}$ September and $15^{\text {th }}$ September) occupied the main plots, the four NPK treatments (Control; 50, 15, $12 \mathrm{~kg} / \mathrm{fed}$ NPK; 75, 30, $24 \mathrm{~kg} /$ fed NPK and 100, 45, $36 \mathrm{~kg} / \mathrm{fed}$ NPK) occupied the sup-plots, and the three micronutriens treatments (Control, spraying after 45 days from transplanting and spraying after 45 and 60 days from transplanting) occupied the sup-sup plots.

The tixture of soil of the experiment area was clay loam. The land of the experiment was left uncultivated on the preceding summer in the two successive seasons. The mechanical and chemical analysis for the soil of the experimental sites are showed in Table (1).

The experimental plot size was $6 \mathrm{~m}^{2}$ consisted of $2.5 \mathrm{~m}$ length and $2.4 \mathrm{~m}$ in width, included four ridges 
with $60 \mathrm{~cm}$ a part between ridges. Onion sets used in the experiment were produced the previous season by using seeds of Giza 6 Mohassan. Planting was done on both sides of the ridge at $7 \mathrm{~cm}$ between plants. The rates of Calcium Super-phosphate $\left(15.5 \% \mathrm{P}_{2} \mathrm{O}_{5}\right)$ and potassium sulphate $\left(48 \% \quad \mathrm{~K}_{2} \mathrm{O}\right)$ were applied during the land preparation, while ammonium nitrate $(33.5 \% \mathrm{~N})$, were applied at two equal doses, after one and two months from planting.

Table 1. The mechanical and chemical analysis for the soil of the experimental sites.

\begin{tabular}{lccc}
\hline \multirow{2}{*}{$\begin{array}{l}\text { Determination } \\
\text { Mechanical }\end{array}$} & Textural & \multicolumn{2}{c}{ Season } \\
\cline { 3 - 4 } analysis & class & $\begin{array}{c}\text { Clay } \\
\text { loam }\end{array}$ & $\begin{array}{c}\text { Clay } \\
\text { loam }\end{array}$ \\
\hline \multirow{4}{*}{ Chemical } & $\mathrm{Ph}$ & 7.8 & 7.7 \\
analysis & EC (m.mhos/cm.) & 0.84 & 0.73 \\
& Organic matter \% & 1.53 & 1.60 \\
& Available N ppm & 18.20 & 20.00 \\
& Available P ppm & 9.6 & 9.00 \\
Cations & Available K ppm & 273 & 257 \\
(meq/100g) & $\mathrm{Ca}$ & 7.00 & 6.59 \\
& $\mathrm{Mg}$ & 2.9 & 2.38 \\
& $\mathrm{Na}$ & 1.50 & 1.58 \\
Anion & $\mathrm{K}$ & 0.24 & 0.33 \\
(meq/100g) & $\mathrm{Co} 3$ & 0.00 & 0.00 \\
& $\mathrm{Hco} 3$ & 2.8 & 2.5 \\
\hline \multirow{2}{*}{ Available } & $\mathrm{So} 4$ & 5.5 & 5.3 \\
nutrients & $\mathrm{Cl}$ & 3.3 & 3.08 \\
(ppm) & $\mathrm{Fe}$ & 10 & 9.4 \\
& $\mathrm{Cu}$ & 0.47 & 0.45 \\
\hline
\end{tabular}

\section{Characters studied:}

A- Vegetative characters: Ten guarded plants were randomly chosen from the $2^{\text {nd }}$ row of each plot at 105 days after planting (DAP) in the two seasons. The following data were recorded for each time: Plant height (cm), number of leaves per plant, plant fresh weight (gm) and plant dry weight (gm).

B. Number of days to maturity: It was counted from transplanting to the maturity stage. Maturity stage was determined based on both softening of bulb neck and $50 \%$ top-down of bulb leaves.

C. Bulb yield and its components: At harvest the following yield parameters were recorded:

1. Total bulbs yield ( $t /$ fed.): It was determined as the weight of the all bulbs from each experimental plot..

2. Single bulbs yield (t/fed.): It was determined as the weight of single bulbs for each experimental plot.

3. Bolters\%: It was estimated by dividing number of bolters by the total number of bulbs x 100 .

4. Double bulbs\%: It was estimated by dividing number of double bulbs by the total number of bulbs x 100 .

E. Bulb quality: At harvest, ten bulbs were randomly taken as a representative sample from each experimental plot and the following physical bulb characters were recorded :

1- Bulb diameter (cm): It was measured by a caliper at the maximum swollen part of the bulb
2- Total soluble solids (T.S.S): It was determined immediately after harvest by a hand refractometer in the same representative sample of the ten bulbs according to A.O.A.C. (1975).

3- Percentage of dry matter in bulbs (D.M.\%): It was determined by estimating the loss in sample of bulbs fresh weight after drying for four hours at $105^{\circ} \mathrm{C}$ and then at $70^{\circ} \mathrm{C}$ in a drying oven with ventilator until it reaches constant weight, according to the following formula:

$$
\text { D.M.\% }=\frac{\text { Sample dry weight }}{\text { Sample fresh weight }} \times 100
$$

\section{Statistical analysis:}

The results of the experiment were subjected to statistical analysis as described by Snedecor and Cochran (1973). Significance among means was tested using LSD method according to Walter and Duncan (1969).

\section{RESULTS AND DISCUSSION}

\section{A. Vegetative growth characteristics: \\ 1- Plant height (cm):}

The results in Table (2) revealed that planting date significantly differentiated plant height in both seasons. The tallest plants were obtained from planting onion sets on $15^{\text {th }}$ September at in first season, and from planting on $1^{\text {st }}$ September in the second season, while the shortest plants were obtained from planting on $15^{\text {th }}$ August in both seasons.

Plant height was increased significantly with increase of NPK rates in both seasons (Table 2). The tallest plants were obtained at the highest NPK rates $(100+45+36 \mathrm{~kg} \mathrm{NPK} / \mathrm{fed}$.), while the shortest plants were obtained from the control treatment, in both seasons. Similar results were obtained by Bungard et al., (1999) and Barker and Pilbeam (2007).

Spraying with micronutrients recorded a significant effect on plant height in both seasons (Table 2). The tallest plants height were obtained from twice micronutrients application after 45, 60 days from transplanting, while the shortest plants were obtained from spraying the control treatment, in both seasons. The above results revealed that plant height was significantly increased by using micronutrients such as zinc, boron, copper, manganese, etc. Zinc, for example, is an active element in biochemical processes and there is chemical and biological interaction between it and some other element such as phosphorus, iron and nitrogen in plants. Boron and Zinc are the most important micronutrient and are essential for cell division, nitrogen and carbohydrate metabolism and water relationships in plant growth. These results were in coinciding with that obtained by Singh and Tiwari (1995), Brady (1990), Abd El-Moneem et al., (2005) and Abd ElSamad (2011).

The effects of double and triple interactions between planting date, NPK levels and micronutrients spraying showed a significant influence on plant height in both seasons, except for the interaction between between NPK treatments and microelement spraying times in the first season. 
Table 2. Effect of planting dates, NPK rates and foliar micronutrients spraying on plant height (cm) of onion grown during 2013/2014 and 2014/2015 seasons.

\begin{tabular}{|c|c|c|c|c|c|c|c|c|c|}
\hline \multirow{3}{*}{ Dates } & \multirow{3}{*}{$\begin{array}{r}\text { Seasons } \\
\text { NPK } \\
\text { rates }\end{array}$} & \multicolumn{4}{|c|}{$2013 / 2014$} & \multicolumn{4}{|c|}{$2014 / 2015$} \\
\hline & & \multicolumn{3}{|c|}{ Micronutrients treatments } & \multirow{2}{*}{ Mean } & \multicolumn{3}{|c|}{ Micronutrients treatments } & \multirow{2}{*}{ Mean } \\
\hline & & Cont. & Once & Twice & & Cont. & Once & Twice & \\
\hline \multirow{4}{*}{$15^{\text {th }}$ Aug. } & Control & 55.20 & 56.33 & 56.57 & 56.03 & 57.43 & 65.43 & 64.20 & 62.36 \\
\hline & $50+15+12 \mathrm{~kg} \mathrm{NPK} / \mathrm{fed}$ & 57.00 & 59.57 & 64.23 & 60.27 & 62.43 & 67.50 & 68.30 & 66.08 \\
\hline & $75+30+24 \mathrm{kgNPK} / \mathrm{fed}$. & 67.00 & 67.20 & 59.87 & 64.69 & 64.63 & 65.30 & 66.30 & 65.41 \\
\hline & $100+45+36 \mathrm{kgNPK} / \mathrm{fed}$ & 59.53 & 71.13 & 65.57 & 65.41 & 68.37 & 74.50 & 68.73 & 70.53 \\
\hline \multirow[t]{2}{*}{ Mean } & & 59.97 & 63.53 & 61.31 & 61.60 & 63.22 & 68.18 & 66.88 & 66.09 \\
\hline & Control & 59.07 & 61.10 & 67.00 & 62.39 & 60.87 & 70.43 & 73.93 & 68.41 \\
\hline \multirow{3}{*}{$1^{\text {st }}$ Sep. } & $50+15+12 \mathrm{~kg} \mathrm{NPK} /$ fed. & 60.73 & 66.63 & 64.50 & 63.96 & 71.53 & 67.17 & 77.20 & 71.97 \\
\hline & $75+30+24 \mathrm{kgNPK} / \mathrm{fed}$ & 65.63 & 65.20 & 73.07 & 67.97 & 68.90 & 78.73 & 72.63 & 73.42 \\
\hline & $100+45+36 \mathrm{kgNPK} / \mathrm{fed}$ & 64.97 & 72.43 & 68.43 & 68.61 & 73.77 & 73.83 & 83.80 & 77.13 \\
\hline \multirow{2}{*}{ Mean } & & 62.60 & 66.34 & 68.25 & 65.73 & 68.77 & 72.54 & 76.89 & 72.73 \\
\hline & Control & 67.10 & 62.73 & 72.87 & 67.57 & 69.47 & 66.87 & 70.13 & 68.82 \\
\hline \multirow{3}{*}{$15^{\text {th }}$ Sep. } & $50+15+12 \mathrm{~kg} \mathrm{NPK} /$ fed. & 80.53 & 77.07 & 74.73 & 77.44 & 66.77 & 67.97 & 67.40 & 67.38 \\
\hline & $75+30+24 \mathrm{kgNPK} / \mathrm{fed}$ & 77.20 & 76.83 & 84.40 & 79.48 & 73.43 & 74.63 & 73.53 & 73.87 \\
\hline & $100+45+36 \mathrm{kgNPK} / \mathrm{fed}$ & 79.33 & 83.40 & 90.20 & 84.31 & 76.93 & 76.83 & 80.83 & 78.20 \\
\hline \multicolumn{2}{|l|}{ Mean } & 76.04 & 75.01 & 80.55 & 77.20 & 71.65 & 71.58 & 72.98 & 72.07 \\
\hline \multirow{4}{*}{$\begin{array}{l}\text { Fert. } \\
\text { Means }\end{array}$} & Control & 60.83 & 60.01 & 65.14 & 62.00 & 62.59 & 67.58 & 69.42 & 66.53 \\
\hline & $50+15+12 \mathrm{~kg}$ NPK $/ \mathrm{fed}$ & 66.09 & 67.76 & 67.82 & 67.22 & 66.91 & 67.54 & 70.97 & 68.47 \\
\hline & $75+30+24 \mathrm{kgNPK} / \mathrm{fed}$ & 69.94 & 69.74 & 72.44 & 70.71 & 68.87 & 72.89 & 70.82 & 70.90 \\
\hline & $100+45+36 \mathrm{kgNPK} / \mathrm{fed}$ & 67.94 & 75.66 & 74.73 & 72.78 & 73.02 & 75.06 & 77.79 & 75.29 \\
\hline \multicolumn{2}{|c|}{ Micronutrients means } & 66.20 & 68.29 & 70.04 & & 67.88 & 70.77 & 72.25 & \\
\hline \multicolumn{10}{|c|}{$\overline{\mathrm{LSD}}$ at 0.05 level of significance } \\
\hline \multirow{2}{*}{\multicolumn{2}{|c|}{ Dates (A) }} & & & & 3.71 & & & & 1.84 \\
\hline & NPK ( B ) & & & & 1.81 & & & & 1.10 \\
\hline \multicolumn{2}{|c|}{ Micronutrients ( C ) } & & & & 3.13 & & & & 1.91 \\
\hline \multicolumn{2}{|l|}{$\mathrm{AX} \mathrm{B}$} & & & & 2.09 & & & & 1.18 \\
\hline \multicolumn{2}{|l|}{$\mathrm{AXC}$} & & & & 3.61 & & & & 2.05 \\
\hline \multicolumn{2}{|l|}{$\mathrm{BX} \mathrm{C}$} & & & & NS & & & & 2.36 \\
\hline \multicolumn{2}{|c|}{$\mathrm{A} \times \mathrm{B} \times \mathrm{C}$} & & & & 7.22 & & & & 4.09 \\
\hline
\end{tabular}

\section{Number of leaves per plant:}

Results in Table (3) revealed that planting date significantly influenced number of leaves per plant in both seasons. The maximum number of leaves/plant were observed by planting on $15^{\text {th }}$ September in both seasons.
While, the minimum number of leaves/plant were obtained by planting on $15^{\text {th }}$ August, in both seasons. These results are in harmony with those recorded by Sayed et al., (2001), Christopher (2003).

Table 3. Effect of planting dates, NPK rates and micronutrients foliar application on number of leaves/plant of onion grown during 2013/2014 and 2014/2015 seasons.

\begin{tabular}{|c|c|c|c|c|c|c|c|c|c|}
\hline \multirow{3}{*}{ Dates } & \multirow{3}{*}{$\begin{array}{r}\text { Seasons } \\
\text { NPK } \\
\text { rates }\end{array}$} & \multicolumn{4}{|c|}{$2013 / 2014$} & \multicolumn{4}{|c|}{$2014 / 2015$} \\
\hline & & \multicolumn{3}{|c|}{ Micronutrients treatments } & \multirow{2}{*}{ Mean } & \multicolumn{3}{|c|}{ Micronutrients treatments } & \multirow{2}{*}{ Mean } \\
\hline & & Cont. & Once & Twice & & Cont. & Once & Twice & \\
\hline \multirow{4}{*}{$15^{\text {th }}$ Aug. } & Control & 7.63 & 8.57 & 7.60 & 7.93 & 7.73 & 7.80 & 9.83 & 8.46 \\
\hline & $50+15+12 \mathrm{~kg} \mathrm{NPK} /$ fed. & 8.10 & 7.83 & 8.67 & 8.07 & 7.40 & 8.70 & 10.87 & 8.99 \\
\hline & $75+30+24 \mathrm{kgNPK} / \mathrm{fed}$ & 9.00 & 9.90 & 8.87 & 9.26 & 8.63 & 9.00 & 11.40 & 9.68 \\
\hline & $100+45+36 \mathrm{kgNPK} / \mathrm{fed}$ & 10.17 & 9.43 & 8.63 & 9.41 & 9.50 & 10.33 & 11.63 & 10.49 \\
\hline \multirow[t]{2}{*}{ Mean } & & 8.73 & 8.83 & 8.44 & 8.67 & 8.32 & 8.96 & 10.93 & 9.40 \\
\hline & Control & 8.87 & 8.50 & 9.03 & 8.80 & 6.83 & 8.10 & 10.37 & 8.43 \\
\hline \multirow{3}{*}{$1^{\text {st }}$ Sep. } & $50+15+12 \mathrm{~kg} \mathrm{NPK} / \mathrm{fed}$ & 9.10 & 8.87 & 9.27 & 9.08 & 10.37 & 9.07 & 11.80 & 10.41 \\
\hline & $75+30+24 \mathrm{kgNPK} / \mathrm{fed}$ & 9.53 & 9.67 & 9.27 & 9.49 & 9.70 & 10.07 & 10.80 & 10.19 \\
\hline & $100+45+36 \mathrm{kgNPK} / \mathrm{fed}$ & 9.40 & 9.83 & 10.13 & 9.79 & 9.43 & 10.27 & 12.10 & 10.60 \\
\hline \multirow[t]{2}{*}{ Mean } & & 9.23 & 9.22 & 9.43 & 9.29 & 9.08 & 9.38 & 11.27 & 9.91 \\
\hline & Control & 8.53 & 8.87 & 8.70 & 8.70 & 10.08 & 8.93 & 10.77 & 9.92 \\
\hline \multirow{3}{*}{$15^{\text {th }}$ Sep. } & $50+15+12 \mathrm{~kg} \mathrm{NPK} /$ fed. & 8.73 & 9.00 & 9.40 & 9.04 & 9.10 & 9.37 & 10.63 & 9.70 \\
\hline & $75+30+24 \mathrm{kgNPK} / \mathrm{fed}$ & 9.40 & 9.43 & 10.13 & 9.66 & 9.43 & 11.47 & 11.33 & 10.74 \\
\hline & $100+45+36 \mathrm{kgNPK} / \mathrm{fed}$ & 9.50 & 9.97 & 11.13 & 10.20 & 10.70 & 11.30 & 13.83 & 11.94 \\
\hline \multicolumn{2}{|l|}{ Mean } & 9.04 & 9.32 & 9.84 & 9.40 & 9.83 & 10.27 & 11.64 & 10.58 \\
\hline \multirow{4}{*}{$\begin{array}{l}\text { Fert. } \\
\text { Means }\end{array}$} & Control & 8.34 & 8.64 & 8.44 & 8.48 & 8.21 & 8.28 & 10.32 & 8.94 \\
\hline & $50+15+12 \mathrm{~kg} \mathrm{NPK} /$ fed. & 8.64 & 8.43 & 9.11 & 8.73 & 8.96 & 9.04 & 11.10 & 9.70 \\
\hline & $75+30+24 \mathrm{kgNPK} / \mathrm{fed}$ & 9.31 & 9.67 & 9.42 & 9.67 & 9.26 & 10.18 & 11.18 & 10.20 \\
\hline & $100+45+36 \mathrm{kgNPK} / \mathrm{fed}$ & 9.68 & 9.74 & 9.97 & 9.80 & 9.88 & 10.63 & 12.52 & 11.01 \\
\hline \multicolumn{2}{|c|}{ Micronutrients means } & 9.00 & 9.12 & 9.24 & & 9.08 & 9.53 & 11.28 & \\
\hline \multicolumn{10}{|c|}{ LSD at 0.05 level of significance } \\
\hline \multicolumn{2}{|c|}{ Dates (A) } & & & & 0.37 & & & & 0.32 \\
\hline \multicolumn{2}{|l|}{ NPK (B) } & & & & 0.23 & & & & 0.45 \\
\hline \multicolumn{2}{|c|}{ Micronutrients ( C ) } & & & & 0.39 & & & & 0.79 \\
\hline \multicolumn{2}{|c|}{ A X B } & & & & 0.20 & & & & 0.29 \\
\hline \multicolumn{2}{|l|}{$\mathrm{AXC}$} & & & & 0.35 & & & & NS \\
\hline \multicolumn{2}{|l|}{$\mathrm{BX} \mathrm{C}$} & & & & 0.41 & & & & 0.59 \\
\hline \multicolumn{2}{|c|}{$\mathrm{A} \times \mathrm{B} \times \mathrm{Cb}$} & & & & 0.71 & & & & 1.02 \\
\hline
\end{tabular}


The results showed that application rates of NPK fertilization significantly affected number of leaves/plant in both seasons (Table 2). Fertilization with the highest rate of NPK $(100+45+36 \mathrm{~kg} \mathrm{NPK} /$ fed.) surpassed all the othe other NPK treatments rates in respect to number of leaves per plant, while the control treatment produced the lowest number of leaves/plant, in both seasons. These results may be due to the increase in the vegetative growth of the onion plants through the effect of these elements in the synthesis of the different components of protein required for leaf development. Similar results were reported by Mozumder et al., (2007), Shaheen et al., (2011) and Shafeek et al. (2013).

Micronutrients foliar application significantly affected number of leaves/plant in both seasons (Table 3). Foliar spraying twice with micronutrients at 45 and 60 days resulted in the maximum number of leaves/plant, while the control treatment resulted in the minimum number of leaves/plant, in both seasons. The favorable effect of micronutrients on plant growth might be due to its role in many physiological processes and cellular functions within the plants. In addition, they play an essential role in improving plant growth, through the biosynthesis of endogenous hormones which are responsible of promoting of plant growth, Metwally (2002), Battal (2004), Hänsch and Mendel (2009) and Manna (2013) reached to the same results.

Number of leaves/plant was significantly affected by all interactions in both seasons, except for the interaction between planting date and micronutrients foliar spraying in the second seasons (Table 3). The maximum number of leaves/plant were recorded from planting on $15^{\text {th }}$ September with highest rate of NPK $(100+45+36 \mathrm{~kg} \mathrm{NPK} /$ fed.) and twice application of micronutrients, in both seasons. The minimum number of leaves/plant were obtained from planting on $15^{\text {th }}$ August without NPK fertilization and with twice macronutrients application in first season and by planting on $15^{\text {st }}$ August without macronutrients fertilization and without micronutrients spraying in the second seasons.

3. Plant fresh weight (g):

Plant fresh weight was significantly affected by planting date, in both seasons (Table 4). Planting on $15^{\text {th }}$ September and $1^{\text {st }}$ September produced the heaviest plant fresh weight in the first and second seasons, while planting on $15^{\text {th }}$ August produced the thinnest plant fresh weight, in both seasons.

Plant fresh weight was significantly affected with fertilization with NPK rates in both seasons. Fertilization with the highest NPK rates $(100+45+36 \mathrm{~kg} \mathrm{NPK} / \mathrm{fed})$ recorded the heaviest fresh weight of plant, while the control treatment gave the lightest one, in both seasons. These results may be be due to that the applying of nitrogen plus phosphorus improving the vegetative growth and accelerating the photosynthesis in storage organs of bulbs and increased allocation to the bulbs. similar results were reported with by Al-Fraihat (2009), Rizk et al., (2012).

Micronutrients foliar application had a significant effect on fresh weight/plant in the second season. The highest fresh weight/plant was obtained from twice foliar application, while the lowest fresh weight/plant were obtained from the control treatment, in both seasons. Similar results were obtained by Abd El-Samad (2011) who found that the heaviest plant fresh weight was resulted by spraying onion plants with micro elements, such finding may be due to the increasing in photosynthetic activity, which lead to an increase in weight of plant.

Table 4. Effect of planting date, NPK rates and micronutrients foliar spraying on plant fresh weight (g) of onion grown during 2013/2014 and 2014/2015 seasons.

\begin{tabular}{|c|c|c|c|c|c|c|c|c|c|}
\hline \multirow{3}{*}{ Date } & \multirow{3}{*}{$\begin{array}{r}\text { Seasons } \\
\text { NPK } \\
\text { rates }\end{array}$} & \multicolumn{4}{|c|}{$2013 / 2014$} & \multicolumn{4}{|c|}{$2014 / 2015$} \\
\hline & & \multicolumn{3}{|c|}{ Micronutrients treatments } & \multirow{2}{*}{ Mean } & \multicolumn{3}{|c|}{ Micronutrients Treatments } & \multirow{2}{*}{ Mean } \\
\hline & & Cont. & Once & Twice & & Cont. & Once & Twice & \\
\hline \multirow{4}{*}{$15^{\text {th }}$ Aug. } & Control & 464.67 & 376.33 & 344.67 & 361.89 & 383.67 & 347.00 & 412.00 & 380.89 \\
\hline & $50+15+12 \mathrm{~kg} \mathrm{NPK} / \mathrm{fed}$ & 336.33 & 326.33 & 414.67 & 359.11 & 358.33 & 406.67 & 411.67 & 392.22 \\
\hline & $75+30+24 \mathrm{kgNPK} / \mathrm{fed}$ & 388.33 & 413.00 & 356.33 & 385.89 & 340.00 & 355.00 & 440.00 & 378.33 \\
\hline & $100+45+36 \mathrm{kgNPK} / \mathrm{fed}$ & 388.00 & 391.33 & 336.33 & 371.89 & 413.33 & 418.33 & 401.67 & 411.11 \\
\hline \multirow[t]{2}{*}{ Mean } & & 369.33 & 376.75 & 363.00 & 369.69 & 373.83 & 381.75 & 416.33 & 390.64 \\
\hline & Control & 416.33 & 431.33 & 393.00 & 413.56 & 323.67 & 462.00 & 400.33 & 395.33 \\
\hline \multirow{3}{*}{$1^{\text {st }}$ Sep. } & $50+15+12 \mathrm{~kg} \mathrm{NPK} / \mathrm{fed}$ & 354.67 & 453.00 & 383.00 & 396.89 & 460.00 & 408.00 & 485.00 & 451.11 \\
\hline & $75+30+24 \mathrm{kgNPK} / \mathrm{fed}$ & 416.33 & 406.33 & 389.67 & 404.11 & 500.00 & 496.67 & 431.67 & 476.11 \\
\hline & $100+45+36 \mathrm{kgNPK} / \mathrm{fed}$ & 429.67 & 419.67 & 429.67 & 426.33 & 500.00 & 475.00 & 505.00 & 493.33 \\
\hline \multirow[t]{2}{*}{ Mean } & & 404.25 & 427.58 & 398.83 & 410.22 & 445.92 & 460.50 & 455.50 & 453.97 \\
\hline & Control & 424.67 & 398.00 & 463.00 & 428.56 & 502.00 & 440.33 & 376.33 & 439.56 \\
\hline \multirow{3}{*}{$15^{\text {th }}$ Sep. } & $50+15+12 \mathrm{~kg} \mathrm{NPK} / \mathrm{fed}$ & 441.33 & 416.33 & 491.33 & 449.67 & 421.67 & 411.67 & 405.00 & 412.78 \\
\hline & $75+30+24 \mathrm{kgNPK} / \mathrm{fed}$ & 489.67 & 423.00 & 469.67 & 460.78 & 385.00 & 488.33 & 446.67 & 440.00 \\
\hline & $100+45+36 \mathrm{kgNPK} / \mathrm{fed}$ & 426.33 & 461.3 & 599.67 & 495.78 & 403.33 & 411.67 & 531.67 & 448.89 \\
\hline \multicolumn{2}{|l|}{$\overline{\text { Mean }}$} & 445.50 & 424.67 & 505.92 & 458.69 & 428.00 & 438.00 & 439.92 & 435.31 \\
\hline \multirow{4}{*}{$\begin{array}{l}\text { Fertiliz. } \\
\text { means }\end{array}$} & Control & 401.89 & 401.89 & 400.22 & 401.33 & 403.11 & 416.44 & 396.22 & 405.26 \\
\hline & $50+15+12 \mathrm{~kg} \mathrm{NPK} / \mathrm{fed}$ & 377.44 & 398.56 & 429.67 & 401.89 & 413.33 & 408.89 & 433.89 & 418.71 \\
\hline & $0+24 \mathrm{kgNPK} / \mathrm{fed}$ & 431.44 & 414.11 & 405.22 & 416.93 & 408.33 & 446.67 & 439.44 & 431.48 \\
\hline & $100+45+36 \mathrm{kgNPK} / \mathrm{fed}$ & 414.67 & 424.11 & 455.22 & 431.33 & 438.89 & 435.00 & 479.44 & 451.11 \\
\hline \multicolumn{2}{|c|}{ Micronutrients means } & 406.36 & 409.67 & 422.58 & & 415.92 & 426.75 & 437.25 & \\
\hline \multicolumn{10}{|c|}{ LSD at 0.05 level of significance } \\
\hline \multicolumn{2}{|c|}{ Dates (A) } & & & & 19.31 & & & & 17.84 \\
\hline \multicolumn{2}{|l|}{ NPK (B ) } & & & & 20.13 & & & & 20.85 \\
\hline \multicolumn{2}{|c|}{ Micronutrients ( C ) } & & & & NS & & & & 36.12 \\
\hline \multicolumn{2}{|c|}{ A X B } & & & & NS & & & & 14.39 \\
\hline \multicolumn{2}{|l|}{ AX C } & & & & 28.27 & & & & NS \\
\hline \multicolumn{2}{|l|}{$\mathrm{BX} \mathrm{C}$} & & & & 32.64 & & & & 28.76 \\
\hline \multicolumn{2}{|c|}{$\mathrm{A} \times \mathrm{B} \times \mathrm{C}$} & & & & 56.55 & & & & 49.85 \\
\hline
\end{tabular}


The double and triple interactions between planting date, NPK fertilization rates and micronutrients foliar spraying had significant effect on fresh weight/plant in both seasons, except for the interaction between planting date and NPK rates in the first season, and the interaction between planting date and micronutrients foliar spraying times in the second season. The greatest fresh weight/plant were obtained by planting on $15^{\text {th }}$ September, highest rates of NPK fertilization $(100+45+36 \mathrm{~kg} \mathrm{NPK} /$ fed.) and spraying twice with micronutrientents in both seasons.

\section{Plant dry weight (g):}

Plant dry weight was statistically affected by planting date during the two seasons (Table 5). Planting on $15^{\text {th }}$ September produced the highest dry weight/plant in both seasons. On the other side, planting on $15^{\text {th }}$ August resulted in the lowest dry weight/plant in both seasons.

Table 5. Effect of planting dates, NPK rates and micronutrients foliar spraying on plant dry weight (g) of onion grown from sets in 2013/2014 and 2014/2015 seasons.

\begin{tabular}{|c|c|c|c|c|c|c|c|c|c|}
\hline \multirow{3}{*}{$\overline{\text { Dates }}$} & \multirow{3}{*}{\begin{tabular}{|r|} 
Seasons \\
NPK \\
rates
\end{tabular}} & \multicolumn{4}{|c|}{ 2013/2014 } & \multicolumn{4}{|c|}{ 2014/2015 } \\
\hline & & \multicolumn{3}{|c|}{ Micronutrients treatments } & \multirow{2}{*}{ Mean } & \multicolumn{3}{|c|}{ Micronutrients treatments } & \multirow{2}{*}{ Mean } \\
\hline & & Cont. & Once & Twice & & Cont. & Once & Twice & \\
\hline \multirow{4}{*}{$15^{\text {th }}$ Aug. } & Control & 31.33 & 33.67 & 35.17 & 33.39 & 24.13 & 18.17 & 27.43 & 23.24 \\
\hline & $50+15+12 \mathrm{~kg} \mathrm{NPK} / \mathrm{fed}$ & 25.83 & 35.67 & 40.33 & 33.94 & 34.43 & 37.83 & 40.53 & 37.60 \\
\hline & $75+30+24 \mathrm{kgNPK} / \mathrm{fed}$ & 36.67 & 37.83 & 33.67 & 36.07 & 36.50 & 35.83 & 42.03 & 38.12 \\
\hline & $100+45+36 \mathrm{kgNPK} / \mathrm{fed}$ & 37.83 & 38.83 & 33.17 & 36.61 & 44.73 & 45.23 & 49.00 & 46.32 \\
\hline Mean & & 32.92 & 36.50 & 35.58 & 35.00 & 34.95 & 34.27 & 39.75 & 36.32 \\
\hline \multirow{4}{*}{$1^{\text {st }}$ Sep. } & Control & 39.17 & 42.83 & 33.50 & 38.50 & 25.57 & 38.37 & 30.93 & 31.62 \\
\hline & $50+15+12 \mathrm{~kg}$ NPK $/$ fed. & 36.00 & 45.50 & 42.33 & 41.28 & 43.17 & 41.90 & 58.23 & 47.77 \\
\hline & 75+30+24 kgNPK/fed. & 42.17 & 42.50 & 37.33 & 40.67 & 50.57 & 51.00 & 37.93 & 46.50 \\
\hline & $100+45+36 \mathrm{kgNPK} / \mathrm{fed}$ & 46.83 & 45.33 & 43.00 & 45.06 & 64.73 & 52.70 & 58.37 & 58.60 \\
\hline \multirow[t]{2}{*}{ Mean } & & 41.04 & 44.04 & 39.04 & 41.38 & 46.01 & 45.99 & 46.37 & 46.12 \\
\hline & Control & 40.50 & 38.50 & 51.17 & 43.39 & 45.63 & 43.23 & 31.37 & 40.08 \\
\hline \multirow{3}{*}{$15^{\text {th }}$ Sep. } & $50+15+12 \mathrm{~kg} \mathrm{NPK} /$ fed. & 44.50 & 40.17 & 52.83 & 45.83 & 50.13 & 47.23 & 52.17 & 49.48 \\
\hline & $75+30+24 \mathrm{kgNPK} / \mathrm{fed}$ & 47.50 & 42.83 & 47.16 & 45.83 & 45.13 & 57.53 & 50.40 & 51.02 \\
\hline & $100+45+36 \mathrm{kgNPK} / \mathrm{fed}$ & 41.50 & 47.83 & 60.00 & 49.78 & 45.83 & 51.13 & 65.10 & 54.02 \\
\hline \multirow[t]{2}{*}{ Mean } & & 43.50 & 42.33 & 52.79 & 46.21 & 46.68 & 49.78 & 49.76 & 48.74 \\
\hline & Control & 37.00 & 38.33 & 39.94 & 38.43 & 31.78 & 33.26 & 29.91 & 31.65 \\
\hline Ferti. & $50+15+12 \mathrm{~kg} \mathrm{NPK} / \mathrm{fed}$ & 35.44 & 40.44 & 45.17 & 40.35 & 42.58 & 42.32 & 50.31 & 45.07 \\
\hline \multirow[t]{2}{*}{ Mean } & $75+30+24 \mathrm{kgNPK} /$ fed. & 42.11 & 41.06 & 39.39 & 41.85 & 44.07 & 48.12 & 43.46 & 45.22 \\
\hline & $100+45+36 \mathrm{kgNPK} / \mathrm{fed}$ & 42.06 & 44.00 & 45.39 & 43.82 & 51.77 & 49.69 & 57.49 & 52.98 \\
\hline Micronutr & nts means & 39.15 & 40.96 & 42.47 & & 42.55 & 43.35 & 45.29 & \\
\hline \multicolumn{10}{|c|}{ LSD at 0.05 level of significance } \\
\hline \multicolumn{2}{|c|}{ Dates ( A ) } & & & & 3.18 & & & & 2.21 \\
\hline NPK ( B ) & & & & & 1.82 & & & & 3.01 \\
\hline \multicolumn{2}{|c|}{ Micronutrients ( C ) } & & & & 1.95 & & & & 2.16 \\
\hline \multicolumn{2}{|l|}{ A X B } & & & & NS & & & & 5.21 \\
\hline \multicolumn{2}{|l|}{$\mathrm{AXC}$} & & & & 2.86 & & & & NS \\
\hline \multicolumn{2}{|l|}{$\mathrm{BX} \mathrm{C}$} & & & & 2.86 & & & & 4.33 \\
\hline \multicolumn{2}{|c|}{$\mathrm{A} X \mathrm{~B} \times \mathrm{C}$} & & & & 2.86 & & & & 7.49 \\
\hline
\end{tabular}

Plant dry weight was statistically increased as NPK rates was increased in both seasons (Tables 5). The highest rates of NPK $(100+45+36 \mathrm{~kg} \mathrm{NPK} / \mathrm{fed})$ resulted in the greatest values of dry weight/plant, while the control treatment recorded the smallest dry weight/plant, in both seasons. These results are in coincides with those reported by Barakat et al. (2004), El-beheidi et aL., (2004), Shaheen et al., (2011), Rizk et al., (2012).

Plant dry weight was statistically increased as micronutrients application was increased in both seasons (Table 5). Foliar spraying twice with micronutrients gave the maximum dry weight/plant, while the control treatment gave the minimum dry weight/plant in both seasons. These results are in line with those obtained by Kirkby and Römheld (2004) and El-mansi and Sharf El-dien (2005).

The double interaction between planting date and NPK rates appeared statistical effect on plant dry weight in second season only, while the interaction between planting date and micronutrients had a statistical effect in the first season only. The double interaction between NPK rates and micronutrients, and the triple interaction between the three factors appeared statistical effect on plant dry weight in both seasons.

\section{B- Days to bulb maturity:}

Results presented in Table (6) indicate that the effect of planting dates on days to bulb maturity was significant in both seasons. Planting on $1^{\text {st }}$ September and $15^{\text {th }}$ September by sets took longest time to mature, while planting on $15^{\text {th }}$ August took shortest time to mature, in both seasons. These results are mainly attributed to low average temperature in late transplanting date during the growth season, reflected increases in plants growth and continues growing which resulted in good canopy able to enhance neck diameter and delayed on maturity. Similar results were obtained by Khokhar (2008), in contrary Singh and Singh (2003) found that planted on $11^{\text {th }}$ September recorded the lowest values of number of days to bulb maturity.

Number of days to maturity significantly increased as levels of NPK increased in both seasons (Table 6). The longest time to mature were obtained by applications of the highest rates of NPK $(100+45+36 \mathrm{~kg} \mathrm{NPK} / \mathrm{fed})$ in both seasons. While, the shortest time to mature resulted from the control treatment in both seasons. These results are mainly attributed to the fact that application of high rates of NPK during the growth season increased plants growth and produced good canopy which enhanced neck diameter and 
delayed the days to maturity. These results were in agreement with that found by Brewester (1994) and Sorensen and Grevsen (2010) who reported that too much nitrogen promoted excessive vegetative growth and delayed maturity. These results are conformity with the findings of Mohamed and Hemida (2004) who found that excessive $\mathrm{N}(120 \mathrm{~kg} / \mathrm{fed}$.) caused a reduction in yield and delayed the maturity.

Number of days to bulb maturity significantly increased as micronutrients rates increased in both seasons (Table 6). The longest time to bulb mature obtained under spraying twice with micro elements in the both seasons, while the shortest time to maturity were reported from the control of micronutrients foliar application in both seasons.

The double interaction among planting date and NPK rates, and between NPK rates and micronutrients fertilization and the triple interaction between the three factors exhibited significant effect on days to maturity, in the first season only, while the interaction between planting date and micronutrients treatments appeared significant effect in both seasons. The longest time to bulb mature were resulted by planting on $1^{\text {st }}$ September with fertilizating with the highest rates of NPK $(100+45+36 \mathrm{~kg}$ $\mathrm{NPK} /$ fed.) and spraying twice with micronutrients in the first season; and by planting on $15^{\text {th }}$ September with fertilizing with the highest rates of NPK $(100+45+36 \mathrm{~kg}$ $\mathrm{NPK} /$ fed.) and spraying twice with micro elements in the second season. On the other side, the shortest time to bulb mature were observed under planting date of $15^{\text {th }}$ August, adding of $50+15+12 \mathrm{~kg} \mathrm{NPK} /$ fed. and control micronutrients treatment in both seasons.

Table 6. Effect of planting date, NPK rates and micronutrients foliar spraying on days to maturity of onion grown from sets in 2013/2014 and 2014/2015 seasons.

\begin{tabular}{|c|c|c|c|c|c|c|c|c|c|}
\hline \multirow{3}{*}{ Dates } & \multirow{3}{*}{$\begin{array}{r}\text { Seasons } \\
\text { NPK } \\
\text { rates }\end{array}$} & \multicolumn{4}{|c|}{$2013 / 2014$} & \multicolumn{4}{|c|}{ 2014/2015 } \\
\hline & & \multicolumn{3}{|c|}{ Micronutrients Treatments } & \multirow{2}{*}{ Mean } & \multicolumn{3}{|c|}{ Micronutrients treatments } & \multirow{2}{*}{ Mean } \\
\hline & & Cont. & Once & Twice & & Cont. & Once & Twice & \\
\hline \multirow{4}{*}{$15^{\text {th }}$ Aug. } & Control & 124.67 & 128.00 & 130.33 & 127.67 & 126.67 & 127.00 & 129.33 & 127.44 \\
\hline & $50+15+12 \mathrm{~kg} \mathrm{NPK} /$ fed. & 124.33 & 126.33 & 131.33 & 127.33 & 124.67 & 126.67 & 131.33 & 127.56 \\
\hline & $75+30+24 \mathrm{kgNPK} / \mathrm{fed}$ & 127.00 & 128.00 & 126.00 & 127.00 & 126.33 & 128.00 & 127.67 & 127.33 \\
\hline & $100+45+36 \mathrm{kgNPK} / \mathrm{fed}$ & 126.00 & 127.33 & 130.67 & 128.00 & 127.33 & 130.00 & 133.00 & 130.11 \\
\hline \multirow[t]{2}{*}{ Mean } & & 125.50 & 127.42 & 129.58 & 127.50 & 126.25 & 127.92 & 130.33 & 128.17 \\
\hline & Control & 131.33 & 136.33 & 141.00 & 136.22 & 127.00 & 128.67 & 132.00 & 129.22 \\
\hline \multirow{3}{*}{$1^{\text {st }}$ Sep. } & $50+15+12 \mathrm{~kg}$ NPK/fed. & 136.67 & 140.67 & 130.33 & 135.89 & 132.00 & 134.33 & 128.33 & 131.56 \\
\hline & $75+30+24 \mathrm{kgNPK} / \mathrm{fed}$ & 137.33 & 139.67 & 133.00 & 136.67 & 130.00 & 132.67 & 128.33 & 130.33 \\
\hline & $100+45+36 \mathrm{kgNPK} / \mathrm{fed}$ & 139.67 & 136.33 & 142.00 & 140.33 & 134.67 & 132.33 & 133.67 & 133.56 \\
\hline \multirow[t]{2}{*}{ Mean } & & 136.25 & 138.25 & 137.33 & 137.28 & 130.92 & 132.00 & 130.58 & 131.17 \\
\hline & Control & 125.33 & 129.00 & 129.00 & 127.78 & 131.00 & 132.67 & 136.00 & 133.22 \\
\hline \multirow{3}{*}{$15^{\text {th }}$ Sep. } & $50+15+12 \mathrm{~kg} \mathrm{NPK} /$ fed. & 129.33 & 130.00 & 133.33 & 130.89 & 130.67 & 133.00 & 138.00 & 133.89 \\
\hline & $75+30+24 \mathrm{kgNPK} / \mathrm{fed}$ & 129.00 & 132.33 & 133.33 & 131.56 & 131.00 & 137.00 & 139.67 & 135.89 \\
\hline & $100+45+36 \mathrm{kgNPK} / \mathrm{fed}$ & 131.33 & 132.67 & 136.67 & 133.56 & 134.33 & 135.33 & 141.60 & 137.22 \\
\hline \multicolumn{2}{|l|}{ Mean } & 128.75 & 131.00 & 133.08 & 130.94 & 131.75 & 134.50 & 138.92 & 135.06 \\
\hline \multirow{4}{*}{$\begin{array}{l}\text { Fert. } \\
\text { Means }\end{array}$} & Control & 127.11 & 131.11 & 133.44 & 130.56 & 128.22 & 129.44 & 132.44 & 130.04 \\
\hline & $50+15+12 \mathrm{~kg} \mathrm{NPK} /$ fed. & 130.11 & 132.33 & 131.67 & 131.37 & 129.11 & 131.33 & 132.56 & 131.00 \\
\hline & $75+30+24 \mathrm{kgNPK} / \mathrm{fed}$ & 131.11 & 133.33 & 130.78 & 131.74 & 129.11 & 132.56 & 131.89 & 131.19 \\
\hline & $100+45+36 \mathrm{kgNPK} / \mathrm{fed}$ & 132.11 & 132.11 & 137.44 & 133.97 & 132.11 & 132.56 & 136.22 & 133.63 \\
\hline \multicolumn{2}{|c|}{ Micronutrients means } & 130.17 & 132.22 & 135.33 & & 129.64 & 131.47 & 134.28 & \\
\hline \multicolumn{10}{|c|}{ LSD at 0.05 level of significance } \\
\hline \multirow{2}{*}{\multicolumn{2}{|c|}{$\begin{array}{l}\text { Date (A) } \\
\text { NPK (B ) }\end{array}$}} & \multicolumn{4}{|c|}{2.96} & & & & 3.02 \\
\hline & & \multicolumn{4}{|c|}{1.08} & & & & 1.32 \\
\hline \multicolumn{2}{|c|}{ Micronutrients ( C ) } & \multicolumn{4}{|c|}{1.87} & & & & 1.33 \\
\hline \multicolumn{2}{|l|}{ A X B } & \multicolumn{4}{|c|}{1.08} & & & & NS \\
\hline \multicolumn{2}{|l|}{ A X C } & \multicolumn{4}{|c|}{1.88} & & & & 2.28 \\
\hline \multicolumn{2}{|l|}{$\mathrm{BX} \mathrm{C}$} & \multicolumn{4}{|c|}{2.17} & & & & NS \\
\hline \multicolumn{2}{|l|}{$\mathrm{AXBXC}$} & & & 3.7 & & & & & NS \\
\hline
\end{tabular}

\section{Total bulb yield and its components:}

1. Total bulbs yield (t/fed.):

The presented results in Table (7) revealed that there is a significant difference on total bulbs yield from planting dates in both seasons. The maximum total bulbs yield were recorded from planting on $15^{\text {th }}$ September, while the minimum values were recorded from planting on $15^{\text {th }}$ August, in both seasons. These results are mainly due to low average temperature in late transplanting date during the growth season, reflected increases in plants growth and resulted in good canopy able to enhance photosynthesis, hence increased dry matter accumulation and in turn increased total bulbs yield/fed. These results are supported by those of Dumitrecu and Radoi (1984) and Shalaby et al. (1991).
The total bulbs yield significantly increased as NPK rates increased in both seasons (Table 7). The highest total bulbs yield were produced from the highest rates of NPK $(100+45+36 \mathrm{~kg} \mathrm{NPK} / \mathrm{fed})$, while the lowest total bulbs yield were obtained from the control treatment, in both seasons. These results may be attributed to that the increase in the application of mineral fertilizers increased plant height, number of leaves/plant and fresh weight/plant, which resulted in an increase in total bulb yield. These results are in agreement with those obtained by Yadave et al., (2002), George et al., (2007), Morsy et al., (2012) and Kandil et al., (2013) and Esawy et al., (2015).

The total bulbs yield was significantly increased by increasing micronutrients application in both seasons (Table 7). The greatest values of total bulbs yield were 
obtained from twice micronutrients application, while the smallest total bulbs yield were obtained from the control treatment, in both seasons. These findings are in harmony with those obtained by Metwally (2002) Chattopadhyay and Mukhopadhyay (2004), Rastegar and Ganjehie (2009) and Mousavi et al., (2013) who concluded that onion total yield significantly increased by increasing micronutrients applications. The effective role of microelements on total yield might be due to its effect on some physiological and chemical processes in plant, which influenced cell enlargement and consequently plant growth, which is reflected on total yield of onion. These results are in close agreement with findings of Singh and Tiwari (1995), Sliman et al., (1999), Khan et al., (2007), Kurtz and Ernani (2010), Abd El-Samad et al., (2011) and Trivedi and Dhumal (2013).

Table 7. Effect of planting date, NPK rates and micronutrients foliar spraying on total bulbs yields (ton/fed.) of onion grown from sets in 2013/2014 and 2014/2015 seasons.

\begin{tabular}{|c|c|c|c|c|c|c|c|c|c|}
\hline \multicolumn{2}{|r|}{ Seasons } & \multicolumn{4}{|c|}{$2013 / 2014$} & \multicolumn{4}{|c|}{$2014 / 2015$} \\
\hline \multirow{2}{*}{ Dates } & \multirow{2}{*}{$\begin{array}{l}\text { NPK } \\
\text { rates }\end{array}$} & \multicolumn{3}{|c|}{ Spraying with microelements } & \multirow{2}{*}{ Mean } & \multicolumn{3}{|c|}{ Spraying with microelements } & \multirow{2}{*}{ Mean } \\
\hline & & Cont. & Once & Twice & & Cont. & Once & Twice & \\
\hline \multirow{4}{*}{$15^{\text {th }}$ Aug. } & Control & 5.69 & 6.15 & 9.00 & 6.95 & 6.13 & 9.17 & 10.00 & 8.433 \\
\hline & $50+15+12 \mathrm{~kg} \mathrm{NPK} / \mathrm{fed}$ & 7.09 & 9.29 & 9.79 & 8.73 & 9.667 & 10.03 & 11.10 & 10.27 \\
\hline & $75+30+24 \mathrm{kgNPK} /$ fed. & 8.93 & 10.48 & 11.00 & 10.13 & 11.37 & 11.33 & 12.20 & 11.63 \\
\hline & $100+45+36 \mathrm{kgNPK} / \mathrm{fed}$ & 9.40 & 11.51 & 11.69 & 10.87 & 12.47 & 12.97 & 13.17 & 12.87 \\
\hline \multirow[t]{2}{*}{ Mean } & & 7.78 & 9.36 & 10.37 & 9.17 & 9.91 & 10.88 & 11.62 & 10.80 \\
\hline & Control & 8.77 & 9.31 & 10.47 & 9.52 & 10.53 & 10.60 & 10.10 & 10.41 \\
\hline \multirow{3}{*}{$1^{\text {st }}$ Sep. } & $50+15+12 \mathrm{~kg} \mathrm{NPK} / \mathrm{fed}$ & 8.56 & 10.37 & 9.927 & 9.62 & 11.50 & 11.90 & 11.40 & 11.60 \\
\hline & $75+30+24 \mathrm{kgNPK} / \mathrm{fed}$ & 10.48 & 11.51 & 10.59 & 10.86 & 12.30 & 12.03 & 12.57 & 12.30 \\
\hline & $100+45+36 \mathrm{kgNPK} / \mathrm{fed}$ & 10.04 & 11.32 & 11.30 & 10.89 & 13.03 & 11.33 & 10.37 & 11.58 \\
\hline \multirow[t]{2}{*}{ Mean } & & 9.46 & 10.63 & 10.57 & 10.22 & 11.84 & 11.47 & 11.11 & 11.47 \\
\hline & Control & 8.57 & 8.28 & 10.88 & 9.24 & 12.03 & 9.50 & 10.20 & 10.58 \\
\hline \multirow{3}{*}{$15^{\text {th }}$ Sep. } & $50+15+12 \mathrm{~kg} \mathrm{NPK} /$ fed. & 11.61 & 10.39 & 12.47 & 11.49 & 12.20 & 11.67 & 13.37 & 12.41 \\
\hline & $75+30+24 \mathrm{kgNPK} / \mathrm{fed}$ & 12.15 & 11.33 & 11.20 & 11.56 & 13.27 & 12.90 & 13.30 & 13.16 \\
\hline & $100+45+36 \mathrm{kgNPK} / \mathrm{fed}$ & 12.52 & 12.46 & 12.70 & 12.69 & 13.50 & 12.93 & 13.77 & 13.40 \\
\hline \multicolumn{2}{|l|}{ Mean } & 11.21 & 10.72 & 11.81 & 11.25 & 12.75 & 11.75 & 12.66 & 12.39 \\
\hline \multirow{4}{*}{$\begin{array}{l}\text { Fert. } \\
\text { Means }\end{array}$} & Control & 7.66 & 7.92 & 10.12 & 8.57 & 9.567 & 9.756 & 10.10 & 9.81 \\
\hline & $50+15+12 \mathrm{~kg} \mathrm{NPK} /$ fed. & 9.09 & 10.02 & 10.73 & 9.95 & 11.12 & 11.20 & 11.96 & 11.43 \\
\hline & $75+30+24 \mathrm{kgNPK} / \mathrm{fed}$ & 10.52 & 11.11 & 10.93 & 10.85 & 12.31 & 12.09 & 12.69 & 12.36 \\
\hline & $100+45+36 \mathrm{kgNPK} / \mathrm{fed}$ & 10.65 & 11.90 & 11.89 & 11.48 & 13.00 & 12.41 & 12.43 & 12.62 \\
\hline \multicolumn{2}{|c|}{ Micronutrients means } & 9.48 & 10.23 & 10.92 & & 11.05 & 11.36 & 11.79 & \\
\hline \multicolumn{10}{|c|}{ LSD at 0.05 level of significance } \\
\hline \multicolumn{2}{|c|}{ Dates (A) } & & & & 0.89 & & & & 0.56 \\
\hline \multicolumn{2}{|l|}{ NPK (B) } & & & & 0.49 & & & & 0.43 \\
\hline \multicolumn{2}{|c|}{ Micronutrients ( C ) } & & & & 0.43 & & & & 0.75 \\
\hline \multicolumn{2}{|l|}{ A X B } & & & & 0.84 & & & & NS \\
\hline \multicolumn{2}{|l|}{$\mathrm{AXC}$} & & & & 0.74 & & & & 0.68 \\
\hline \multicolumn{2}{|l|}{$\mathrm{BX} \mathrm{C}$} & & & & 0.85 & & & & NS \\
\hline \multicolumn{2}{|c|}{$\mathrm{AXBXC}$} & & & & NS & & & & 1.36 \\
\hline
\end{tabular}

The results presented in Table (7) clear that the double interaction among planting dates, NPK rates and between NPK rates and micronutrients treatments had significant effect on total bulbs yield in the first season only, while the interaction between planting dates and micronutrients treatments had significant effect in both seasons. The triple interaction between three factors had a significant effect in the second season only. The highest total bulbs yield was obtained by planting on $15^{\text {th }}$ September, adding higher rate of NPK $(100+45+36 \mathrm{~kg} \mathrm{NPK} /$ fed. $)$ and spraying twice with micro elements, while the lowest total bulbs yield was obtained by planting on $15^{\text {th }}$ August, control of NPK rates and the control of micronutrients in both seasons. It was concluded that the late sowing date and application of high doses of NPK and micro nutrients promoted plant growth and accumulation of dry matter thus, high yields have been obtained. These results are in coincide with those obtained by Al Abdulsalam and Hamaiel (2004).

\section{Single bulbs yield (t/fed.):}

The effect of planting dates on single bulb yield was significant in both seasons (Table 8 ). The greatest bulb yield (4.69 and $5.20 \mathrm{t} /$ fed.) were obtained by planting on $15^{\text {th }}$ September and $1^{\text {st }}$ September in the first and second seasons, respectively. While the smallest values (3.43 and
$3.62 \mathrm{t} / \mathrm{fed}$.) were obtained by planting on $15^{\text {th }}$ August, in the first and second seasons, respectively. These results mainly attributed to decreasing of bolting $\%$ and doubling $\%$ under early planting date as compared to late planting date as the results of increasing the temperature in the beginning of the season, which is unfavorable for these two phenomenons. Similar results were obtained by Shalaby et al., (1991) and El-Gamili and Abd El-Hadi (1996).

Single bulbs yield was insignificantly affected by NPK rates in both seasons (Table 8 ). The maximum single bulb yield were obtained from the highest rates of NPK fertilizers $(100+45+36 \mathrm{~kg}$ NPK /fed NPK) in the first season and at rate of $50+15+12 \mathrm{~kg} \mathrm{NPK} / \mathrm{fed}$. in the second season. The minimum single bulb yield were observed from the control NPK in both seasons.

Micronutrients application had insignificant effect on single bulb yield in both seasons. The highest single bulb yield were obtained from spraying twice with micro elements, while the lowest single bulb yield were obtained from the control treatment in both seasons.

The different interactions between three factors had insignificant effect on single bulb yield in both seasons, except the interaction between planting date and NPK rates in the second season (Table 8). 
Mohamed, A. G. et al.

Table 8. Effect of planting date, NPK rates and micronutrients foliar spraying on single bulb yield (ton/fed.) of onion sets in 2013/2014 and 2014/2015 seasons.

\begin{tabular}{|c|c|c|c|c|c|c|c|c|c|}
\hline \multicolumn{2}{|r|}{ Seasons } & \multicolumn{4}{|c|}{ 2013/2014 } & \multicolumn{4}{|c|}{ 2014/2015 } \\
\hline \multirow{2}{*}{ Dates } & \multirow{2}{*}{$\begin{array}{l}\text { NPK } \\
\text { rates }\end{array}$} & \multicolumn{3}{|c|}{ Micronutrients treatments } & \multirow{2}{*}{ Mean } & \multicolumn{3}{|c|}{ Micronutrients treatments } & \multirow{2}{*}{ Mean } \\
\hline & & cont. & Once & Twice & & Cont. & Once & Twice & \\
\hline \multirow{4}{*}{$15^{\text {th }}$ Aug. } & Control & 3.40 & 3.47 & 3.63 & 3.50 & 3.34 & 3.28 & 3.48 & 3.37 \\
\hline & $50+15+12 \mathrm{~kg} \mathrm{NPK} / \mathrm{fed}$. & 3.03 & 3.63 & 3.53 & 3.40 & 4.22 & 4.08 & 3.77 & 4.02 \\
\hline & 75+30+24 kgNPK/fed. & 3.40 & 3.30 & 3.40 & 3.37 & 3.00 & 3.33 & 3.58 & 3.30 \\
\hline & $100+45+36 \mathrm{kgNPK} / \mathrm{fed}$ & 3.33 & 3.60 & 3.43 & 3.46 & 4.30 & 3.07 & 3.97 & 3.78 \\
\hline \multirow[t]{2}{*}{ Mean } & & 3.29 & 3.50 & 3.50 & 3.43 & 3.72 & 3.44 & 3.70 & 3.62 \\
\hline & Control & 4.37 & 4.60 & 4.50 & 4.49 & 4.63 & 5.32 & 4.80 & 4.92 \\
\hline $1^{\text {st }}$ & $50+15+12 \mathrm{~kg} \mathrm{NPK} /$ fed. & 4.33 & 4.63 & 3.97 & 4.31 & 4.73 & 5.07 & 4.98 & 4.93 \\
\hline \multirow[t]{2}{*}{ Sep. } & 75+30+24 kgNPK/fed. & 4.53 & 4.13 & 4.37 & 4.34 & 5.48 & 5.72 & 5.42 & 5.54 \\
\hline & $100+45+36 \mathrm{kgNPK} / \mathrm{fed}$ & 4.60 & 4.40 & 3.90 & 4.30 & 5.14 & 5.19 & 5.90 & 5.41 \\
\hline \multirow[t]{2}{*}{ Mean } & & 4.46 & 4.44 & 4.18 & 4.36 & 4.99 & 5.32 & 5.28 & 5.20 \\
\hline & Control & 4.67 & 4.77 & 4.77 & 4.73 & 4.55 & 4.19 & 5.44 & 4.73 \\
\hline \multirow{3}{*}{$15^{\text {th }}$ Sep. } & $50+15+12 \mathrm{~kg}$ NPK/fed. & 4.20 & 4.37 & 4.80 & 4.46 & 5.50 & 5.91 & 5.17 & 5.53 \\
\hline & 75+30+24 kgNPK/fed. & 4.53 & 3.97 & 5.07 & 4.52 & 4.27 & 5.82 & 4.46 & 4.85 \\
\hline & $100+45+36 \mathrm{kgNPK} / \mathrm{fed}$ & 4.70 & 5.30 & 5.17 & 5.06 & 4.36 & 4.53 & 4.77 & 4.55 \\
\hline \multirow[t]{2}{*}{ Mean } & & 4.53 & 4.60 & 4.95 & 4.69 & 4.67 & 5.11 & 4.96 & 4.91 \\
\hline & Control & 4.14 & 4.28 & 4.30 & 4.24 & 4.17 & 4.26 & 4.57 & 4.34 \\
\hline Fert. & $50+15+12 \mathrm{~kg}$ NPK $/$ fed. & 3.86 & 4.21 & 4.10 & 4.06 & 4.82 & 5.02 & 4.64 & 4.83 \\
\hline \multirow[t]{2}{*}{ Means } & $75+30+24 \mathrm{kgNPK} /$ fed. & 4.16 & 3.80 & 4.28 & 4.08 & 4.25 & 4.96 & 4.49 & 4.56 \\
\hline & $100+45+36 \mathrm{kgNPK} / \mathrm{fed}$ & 4.21 & 4.43 & 4.17 & 4.27 & 4.60 & 4.26 & 4.88 & 4.58 \\
\hline \multicolumn{2}{|c|}{ Micronutrients means } & 4.09 & 4.18 & 4.21 & & 4.46 & 4.63 & 4.65 & \\
\hline \multirow{2}{*}{\multicolumn{2}{|c|}{$\begin{array}{l}\text { LSD at } 0.05 \text { level of significance } \\
\text { Dates (A) }\end{array}$}} & & & & & & & & \\
\hline & & & & 0.17 & & & & & 0.73 \\
\hline \multicolumn{2}{|l|}{ NPK (B) } & & & NS & & & & & NS \\
\hline \multicolumn{2}{|c|}{ Micronutrients ( C ) } & & & NS & & & & & NS \\
\hline \multicolumn{2}{|l|}{$\mathrm{A} X \mathrm{~B}$} & & & NS & & & & & 0.63 \\
\hline \multicolumn{2}{|l|}{$\mathrm{A} X \mathrm{C}$} & & & NS & & & & & NS \\
\hline \multirow{2}{*}{\multicolumn{2}{|c|}{$\begin{array}{l}\mathrm{BXC} \\
\mathrm{AXB} \times \mathrm{C}\end{array}$}} & & & NS & & & & & NS \\
\hline & & & & NS & & & & & NS \\
\hline
\end{tabular}

\section{Bolters percentage:}

Results presented in Table (9) showed that the effect of planting dates on bolters $\%$ was significant in both seasons. Planting on $15^{\text {th }}$ September resulted in the greatest percentage of bolters, while planting on $15^{\text {th }}$ August resulted in the smallest values, in both seasons. It was found that bolting percentage tended to increase with late planting of sets. This results may be attributed to that the plants which planted late in the season exposed to long periods at cool temperature before they start to bulb and this induced vernalization for bulbs, which resulted in the highest percentage of bolting bulbs. Similar results were obtained by Farghali et al., (1991), Shalaby et al., (1991) and Christopher (2003).

Table 9. Effect of planting date, NPK rates and micronutrients foliar spraying on bolters percentage of onion grown from sets in 2013/2014 and 2014/2015 seasons.

\begin{tabular}{|c|c|c|c|c|c|c|c|c|c|}
\hline \multirow{3}{*}{ Dates } & \multirow{3}{*}{$\begin{array}{r}\text { Seasons } \\
\text { NPK } \\
\text { rates }\end{array}$} & \multicolumn{4}{|c|}{$2013 / 2014$} & \multicolumn{4}{|c|}{$2014 / 2015$} \\
\hline & & \multicolumn{3}{|c|}{ Spraying with microelements } & \multirow{2}{*}{ Mean } & \multicolumn{3}{|c|}{ Spraying with microelements } & \multirow[t]{2}{*}{ Mean } \\
\hline & & Cont. & Once & Twice & & contr. & Once & Twice & \\
\hline \multirow{4}{*}{$15^{\text {th }}$ Aug. } & Control & 3.53 & 5.11 & 3.50 & 4.05 & 4.70 & 3.60 & 6.43 & 4.91 \\
\hline & $50+15+12 \mathrm{~kg}$ NPK$/$ fed. & 4.60 & 4.27 & 2.98 & 4.26 & 5.00 & 5.40 & 3.20 & 5.53 \\
\hline & $75+30+24 \mathrm{kgNPK} / \mathrm{fed}$ & 6.82 & 4.56 & 6.43 & 5.94 & 3.87 & 4.10 & 4.53 & 4.17 \\
\hline & $100+45+36 \mathrm{kgNPK} / \mathrm{fed}$ & 9.71 & 5.57 & 7.36 & 7.55 & 3.80 & 8.73 & 6.80 & 6.44 \\
\hline \multirow[t]{2}{*}{ Mean } & & 6.17 & 4.88 & 5.31 & 5.37 & 5.09 & 5.46 & 5.24 & 5.26 \\
\hline & Control & 6.79 & 4.31 & 8.07 & 6.30 & 5.87 & 6.07 & 7.67 & 6.53 \\
\hline \multirow{3}{*}{$1^{\text {st }}$ Sep. } & $50+15+12 \mathrm{~kg} \mathrm{NPK} /$ fed. & 5.45 & 6.55 & 7.46 & 6.48 & 7.47 & 8.17 & 8.57 & 8.07 \\
\hline & $75+30+24 \mathrm{kgNPK} / \mathrm{fed}$ & 7.85 & 8.32 & 7.81 & 6.66 & 7.63 & 9.07 & 8.87 & 8.52 \\
\hline & $100+45+36 \mathrm{kgNPK} / \mathrm{fed}$ & 8.19 & 8.24 & 7.72 & 8.72 & 8.03 & 7.83 & 9.00 & 8.52 \\
\hline \multirow[t]{2}{*}{ Mean } & & 6.07 & 7.36 & 7.76 & 7.06 & 7.25 & 7.78 & 7.80 & 7.91 \\
\hline & Control & 6.20 & 8.37 & 9.13 & 7.90 & 8.53 & 8.33 & 8.77 & 8.51 \\
\hline \multirow{3}{*}{$15^{\text {th }}$ Sep. } & $50+15+12 \mathrm{~kg} \mathrm{NPK} /$ fed. & 7.41 & 9.17 & 9.24 & 8.60 & 8.33 & 8.70 & 9.67 & 8.90 \\
\hline & $75+30+24 \mathrm{kgNPK} / \mathrm{fed}$ & 7.16 & 9.21 & 9.10 & 7.49 & 9.00 & 8.43 & 9.57 & 9.00 \\
\hline & $100+45+36 \mathrm{kgNPK} / \mathrm{fed}$ & 7.66 & 9.20 & 9.63 & 6.49 & 9.40 & 7.83 & 9.77 & 8.90 \\
\hline \multicolumn{2}{|l|}{ Mean } & 7.11 & 7.99 & 7.77 & 7.62 & 8.82 & 8.30 & 9.37 & 8.83 \\
\hline \multirow{4}{*}{$\begin{array}{l}\text { Fert. } \\
\text { Mean }\end{array}$} & Control & 5.51 & 5.93 & 6.90 & 6.11 & 6.37 & 5.97 & 7.62 & 6.65 \\
\hline & $50+15+12 \mathrm{~kg} \mathrm{NPK} /$ fed. & 5.82 & 6.66 & 6.56 & 6.35 & 7.93 & 7.42 & 7.14 & 7.50 \\
\hline & $75+30+24 \mathrm{kgNPK} / \mathrm{fed}$ & 5.94 & 7.36 & 6.78 & 6.70 & 6.83 & 7.20 & 7.66 & 7.23 \\
\hline & $100+45+36 \mathrm{kgNPK} / \mathrm{fed}$ & 8.52 & 7.00 & 7.24 & 7.59 & 7.08 & 8.13 & 8.66 & 7.96 \\
\hline \multicolumn{2}{|c|}{ Micronutrients means } & 6.45 & 6.74 & 6.95 & & 7.05 & 7.18 & 8.77 & \\
\hline \multirow{2}{*}{\multicolumn{2}{|c|}{$\begin{array}{l}\text { LSD at } 0.05 \text { level of significance } \\
\text { Dates (A) }\end{array}$}} & & & & & & & & \\
\hline & & & & & 1.39 & & & & 0.40 \\
\hline \multicolumn{2}{|c|}{ NPK (B) } & & & & 0.74 & & & & 0.60 \\
\hline \multicolumn{2}{|c|}{ Micronutrients ( C ) } & & & & NS & & & & 1.05 \\
\hline \multirow{2}{*}{\multicolumn{2}{|c|}{$\begin{array}{l}\text { A X B } \\
\text { A X C }\end{array}$}} & & & & 1.29 & & & & 0.54 \\
\hline & & & & & NS & & & & NS \\
\hline \multicolumn{2}{|l|}{$\mathrm{BX} \mathrm{C}$} & & & & NS & & & & 1.08 \\
\hline \multicolumn{2}{|c|}{$\mathrm{A} \times \mathrm{B} \times \mathrm{C}$} & & & & NS & & & & 1.88 \\
\hline
\end{tabular}


Bolters \% statisticaly increased as NPK rates increased in both seasons (Table 9). The highest bolters percentage were observed by applying the highest rates of NPK $(100+45+36 \mathrm{~kg}$ NPK /fed), while the lowest bolter percentage were observed by control treatment, in both seasons. Similar results were found by Mohamed and Hemida (2004) and Abdissa et al (2011).

Micronutrients application had a significant effect on bolters percentage in the second season only (Table 9). The highest values of bolters percentage were obtained from spraying twice with micro elements application, while the lowest values were obtained from control treatment in both seasons.

Results presented in Table (9) revealed that the double interaction among planting date, NPK rates had a statistical effect on bolters $\%$ in both seasons, while the interaction between NPK rates and micronutrients and between the three factors had a statistical effect in the second season only. The greatest bolters percentage were obtained from planting on $15^{\text {th }}$ September with higher rates of NPK $(100+45+36 \mathrm{~kg}$ NPK/fed. $)$ and twice micronutrients foliar application, while the smallest bolters percentage were obtained by planting on $15^{\text {th }}$ Agust with application of $50+15+12 \mathrm{~kg} \mathrm{NPK} / \mathrm{fed}$. and twice micronutrients foliar application, in both seasons.

\section{Double bulbs percentage:}

The effect of planting dates on double bulb\% was significant in both seasons (Table 10). The highest percentages of double bulbs were resulted from planting on $15^{\text {th }}$ September, while the lowest percentages were obtained by planting on $15^{\text {th }}$ August, in both seasons.

Table 10. Effect of planting date, NPK rates and micronutrients foliar spraying on double bulbs percentage of onion grown from sets in 2013/2014 and 2014/2015 seasons.

\begin{tabular}{|c|c|c|c|c|c|c|c|c|c|}
\hline \multicolumn{2}{|r|}{ Seasons } & \multicolumn{4}{|c|}{$2013 / 2014$} & \multicolumn{4}{|c|}{$2014 / 2015$} \\
\hline \multirow{2}{*}{ Date } & \multirow{2}{*}{$\begin{array}{l}\text { NPK } \\
\text { rates }\end{array}$} & \multicolumn{3}{|c|}{ Micronutrients treatments } & \multirow{2}{*}{ Mean } & \multicolumn{3}{|c|}{ Micronutrients treatments } & \multirow{2}{*}{ Mean } \\
\hline & & Cont. & Once & Twice & & contr. & Once & Twice & \\
\hline \multirow{4}{*}{$15^{\text {th }}$ Aug. } & Control & 34.33 & 30.17 & 38.04 & 34.18 & 30.20 & 37.73 & 41.33 & 37.24 \\
\hline & $50+15+12 \mathrm{~kg} \mathrm{NPK} / \mathrm{fed}$ & 48.33 & 30.94 & 40.97 & 42.41 & 37.30 & 33.73 & 41.27 & 33.80 \\
\hline & $75+30+24 \mathrm{kgNPK} / \mathrm{fed}$ & 32.79 & 40.08 & 36.98 & 36.61 & 42.67 & 41.67 & 34.30 & 39.5 \\
\hline & $100+45+36 \mathrm{kgNPK} / \mathrm{fed}$ & 42.64 & 39.74 & 38.93 & 37.43 & 36.03 & 40.40 & 42.62 & 39.69 \\
\hline$\overline{\text { Mean }}$ & & 39.77 & 32.73 & 41.22 & 37.91 & 34.05 & 38.13 & 39.91 & 37.37 \\
\hline \multirow{4}{*}{$1^{\text {st }}$ Sep. } & Control & 38.22 & 36.81 & 43.26 & 39.43 & 42.27 & 39.17 & 39.00 & 40.18 \\
\hline & $50+15+12 \mathrm{~kg} \mathrm{NPK} / \mathrm{fed}$ & 30.05 & 35.35 & 40.04 & 35.15 & 42.82 & 44.27 & 36.87 & 41.36 \\
\hline & $75+30+24 \mathrm{kgNPK} / \mathrm{fed}$ & 34.34 & 45.98 & 48.30 & 42.87 & 41.77 & 41.53 & 36.30 & 39.87 \\
\hline & $100+45+36 \mathrm{kgNPK} / \mathrm{fed}$ & 39.51 & 46.00 & 47.27 & 44.29 & 45.62 & 36.13 & 42.70 & 41.83 \\
\hline$\overline{\text { Mean }}$ & & 35.53 & 41.03 & 44.74 & 40.43 & 42.15 & 40.30 & 38.97 & 40.81 \\
\hline \multirow{4}{*}{$15^{\text {th }}$ Sep. } & Control & 38.14 & 37.77 & 42.43 & 39.45 & 42.00 & 42.77 & 42.63 & 42.80 \\
\hline & $50+15+12 \mathrm{~kg} \mathrm{NPK} / \mathrm{fed}$ & 37.41 & 45.51 & 45.28 & 42.93 & 41.00 & 40.30 & 44.10 & 41.80 \\
\hline & $75+30+24 \mathrm{kgNPK} / \mathrm{fed}$ & 38.39 & 44.78 & 44.12 & 42.43 & 42.53 & 42.37 & 44.80 & 43.90 \\
\hline & $100+45+36 \mathrm{kgNPK} / \mathrm{fed}$ & 37.14 & 46.18 & 45.59 & 42.30 & 42.27 & 41.87 & 45.50 & 43.24 \\
\hline \multirow[t]{2}{*}{ Mean } & & 37.75 & 43.58 & 43.86 & 41.73 & 42.47 & 42.08 & 44.26 & 42.93 \\
\hline & Control & 37.90 & 34.92 & 41.24 & 37.69 & 38.52 & 39.89 & 40.99 & 38.80 \\
\hline Fert. & $50+15+12 \mathrm{~kg} \mathrm{NPK} / \mathrm{fed}$ & 38.60 & 37.27 & 45.43 & 40.23 & 37.04 & 39.13 & 40.78 & 39.99 \\
\hline \multirow[t]{2}{*}{ mean } & $75+30+24 \mathrm{kgNPK} / \mathrm{fed}$ & 35.13 & 42.64 & 42.13 & 40.63 & 42.33 & 42.19 & 38.89 & 41.10 \\
\hline & $100+45+36 \mathrm{kgNPK} / \mathrm{fed}$ & 40.64 & 40.64 & 43.40 & 41.25 & 41.68 & 39.47 & 43.61 & 41.59 \\
\hline \multicolumn{2}{|c|}{ Micronutrients means } & 37.68 & 39.12 & 42.28 & & 39.89 & 40.17 & 41.04 & \\
\hline \multicolumn{10}{|c|}{ LSD at 0.05 level of significance } \\
\hline \multicolumn{2}{|c|}{ Dates (A) } & & & & 2.79 & & & & 1.50 \\
\hline \multicolumn{2}{|c|}{ NPK (B ) } & & & & 2.97 & & & & 2.18 \\
\hline \multicolumn{2}{|c|}{ Micronutrients ( C ) } & & & & 3.45 & & & & NS \\
\hline \multicolumn{2}{|l|}{ A X B } & & & & 2.19 & & & & NS \\
\hline \multicolumn{2}{|l|}{$\mathrm{AXC}$} & & & & 2.86 & & & & 2.24 \\
\hline \multicolumn{2}{|l|}{$\mathrm{BX} \mathrm{C}$} & & & & 2.86 & & & & 2.58 \\
\hline \multicolumn{2}{|c|}{$\mathrm{A} \times \mathrm{B} \times \mathrm{C}$} & & & & 7.59 & & & & 4.48 \\
\hline
\end{tabular}

Double bulbs percentage significantly increased as NPK rates increased in both seasons (Table 10). The highest NPK rates $(100+45+36 \mathrm{~kg}$ NPK $/$ fed $)$ appeared the highest percentages of double bulbs, while the control treatment appeared the lowest percentages, in both seasons. These results are in agreeement with those reported by May et al. (2007) and Al-Fraihat (2009).

Micronutrients foliar application had a statistical effect on double bulbs $\%$ in the first season only (Table 10). The highest percentages of double bulbs were resulted from twice micronutrient foliar application, while the lowest percentages were resulted from the control treatment, in both seasons.

Results presented in Table (10) showed that the double and triple interactions among planting date, NPK rates and micronutrients foliar spraying had a statistical effect on double bulbs $\%$ in both seasons, except for the interaction between planting date and NPK rates in the second season.

\section{Bulb quality:}

\section{Bulb diameter (cm):}

Planting dates had a significant effect on bulb diameter in both seasons (Table 11). The maximum bulb 
diameter was recorded by planting on $15^{\text {th }}$ September, while the minimum bulb diameter were recorded by planting on $15^{\text {th }}$ August, in both seasons. Late planting produced larger bulbs than the early planted plants. Plant that produced smaller bulb may be explained by the fact that these plants did not receive a long cool growing period, which is essential for proper development for the bulbs.

The bulb diameter increased significantly as NPK rates was increased in both seasons (Table 11). The highest bulb diameter were obtained at the highest macro fertilizers rates $(100+45+36 \mathrm{NPK} \mathrm{kg} / \mathrm{fed}) \mathrm{NPK}$ in both seasons, while the lowest values were resulted from control treatment in both seasons. These results might be due to that applying nitrogen plus phosphorus improving the vegetative growth and accelerating the photosynthesis in storage organs of bulbs which resulting in an increase in diameter of the bulb. These results are in coincides with those of Poornima (2007), and Abdissa et al. (2011), Soleymani and Shahrajabian (2012) and Shah Saud et al. (2013).

Micro element application had insignificant effect on bulb diameter in both seasons (Table 11). The maximum values of bulb diameter were obtained from twice micro elements application, while the minimum values were obtained from the control treatment, in both seasons.

Results presented in Table (11) stated that the different interactions between the three factors had a significant effect on bulb diameter in both seasons, except for these between planting date and micronutrients spraying in the second season, and between NPK rates and micronutrients spraying in the first season.

Table 11. Effect of planting date, NPK rates and micronutrients foliar spraying on bulb diameter (cm) of onion grown from sets in 2013/2014 and 2014/2015 seasons.

\begin{tabular}{|c|c|c|c|c|c|c|c|c|c|}
\hline \multicolumn{2}{|r|}{ Seasons } & \multicolumn{4}{|c|}{$2013 / 2014$} & \multicolumn{4}{|c|}{$2014 / 2015$} \\
\hline \multirow{2}{*}{ Date } & \multirow{2}{*}{$\begin{array}{l}\text { NPK } \\
\text { rates }\end{array}$} & \multicolumn{3}{|c|}{ Micronutrients treatments } & \multirow{2}{*}{ Mean } & \multicolumn{3}{|c|}{ Micronutrients Treatments } & \multirow{2}{*}{ Mean } \\
\hline & & Cont. & Once & Twice & & Cont. & Once & Twice & \\
\hline & Control & 5.64 & 5.88 & 6.20 & 5.91 & 5.81 & 6.33 & 6.33 & 6.16 \\
\hline $15^{\text {th }}$ & $50+15+12 \mathrm{~kg} \mathrm{NPK} /$ fed. & 6.41 & 6.65 & 6.41 & 6.49 & 6.72 & 6.65 & 6.54 & 6.64 \\
\hline \multirow[t]{2}{*}{ Aug. } & $75+30+24 \mathrm{kgNPK} / \mathrm{fed}$ & 6.75 & 6.85 & 6.79 & 6.80 & 6.51 & 6.93 & 6.79 & 6.74 \\
\hline & $100+45+36 \mathrm{kgNPK} / \mathrm{fed}$ & 7.46 & 7.11 & 7.32 & 7.29 & 7.11 & 6.93 & 7.07 & 7.04 \\
\hline \multicolumn{2}{|l|}{ Mean } & 6.56 & 6.63 & 6.68 & 6.63 & 6.54 & 6.71 & 6.69 & 6.65 \\
\hline \multirow{4}{*}{$1^{\text {st }}$ Sep. } & Control & 6.65 & 6.37 & 6.23 & 6.42 & 6.20 & 6.33 & 6.65 & 6.39 \\
\hline & $50+15+12 \mathrm{~kg} \mathrm{NPK} /$ fed. & 6.51 & 6.62 & 6.33 & 6.49 & 6.93 & 6.90 & 6.83 & 6.89 \\
\hline & $75+30+24 \mathrm{kgNPK} / \mathrm{fed}$ & 7.07 & 6.75 & 6.62 & 6.81 & 7.04 & 6.72 & 7.04 & 6.93 \\
\hline & $100+45+36 \mathrm{kgNPK} / \mathrm{fed}$ & 7.07 & 7.11 & 7.28 & 7.15 & 7.07 & 7.14 & 6.72 & 6.97 \\
\hline \multicolumn{2}{|l|}{ Mean } & 6.83 & 6.71 & 6.62 & 6.72 & 6.80 & 6.77 & 6.80 & 6.75 \\
\hline \multirow{4}{*}{$15^{\text {th }}$ Sep. } & Control & 6.33 & 6.41 & 6.12 & 6.29 & 6.51 & 6.75 & 6.44 & 6.57 \\
\hline & $50+15+12 \mathrm{~kg} \mathrm{NPK} /$ fed. & 6.62 & 6.75 & 6.86 & 6.74 & 6.86 & 6.79 & 6.51 & 6.72 \\
\hline & $75+30+24 \mathrm{kgNPK} / \mathrm{fed}$ & 6.72 & 6.79 & 6.83 & 6.78 & 7.14 & 6.65 & 6.79 & 6.86 \\
\hline & $100+45+36 \mathrm{kgNPK} / \mathrm{fed}$ & 7.25 & 7.42 & 7.35 & 7.34 & 6.83 & 7.28 & 7.25 & 7.12 \\
\hline \multirow[t]{2}{*}{ Mean } & & 6.62 & 6.85 & 6.79 & 6.78 & 6.84 & 6.87 & 6.75 & 6.81 \\
\hline & Control & 6.21 & 6.22 & 6.18 & 6.21 & 6.17 & 6.48 & 6.48 & 6.37 \\
\hline Fert. & $50+15+12 \mathrm{~kg} \mathrm{NPK} /$ fed. & 6.51 & 6.68 & 6.53 & 6.57 & 6.84 & 6.78 & 6.63 & 6.75 \\
\hline \multirow[t]{2}{*}{ Mean } & $75+30+24 \mathrm{kgNPK} / \mathrm{fed}$ & 6.85 & 6.80 & 6.74 & 6.79 & 6.90 & 6.76 & 6.87 & 6.85 \\
\hline & $100+45+36 \mathrm{kgNPK} / \mathrm{fed}$ & 7.26 & 7.21 & 7.32 & 7.27 & 7.00 & 7.39 & 7.50 & 7.05 \\
\hline \multicolumn{2}{|c|}{ Micronutrients means } & 6.50 & 6.73 & 6.91 & & 6.73 & 7.01 & 7.12 & \\
\hline \multicolumn{10}{|c|}{ LSD at 0.05 level of significance } \\
\hline \multicolumn{2}{|c|}{ Dates (A) } & \multicolumn{4}{|r|}{0.11} & & & \multicolumn{2}{|r|}{0.13} \\
\hline \multicolumn{2}{|c|}{ NPK ( B ) } & \multicolumn{4}{|r|}{0.11} & & & \multicolumn{2}{|r|}{0.11} \\
\hline \multicolumn{2}{|c|}{ Micronutrients ( C ) } & \multicolumn{4}{|r|}{ NS } & & & \multicolumn{2}{|r|}{ NS } \\
\hline \multicolumn{2}{|c|}{ AX B } & \multicolumn{4}{|r|}{0.20} & & & & 0.19 \\
\hline $\mathrm{A} X \mathrm{C}$ & & & & & 0.15 & & & & NS \\
\hline BX C & & & & & NS & & & & 0.22 \\
\hline $\mathrm{A} X \mathrm{~B} X$ & & & & & 0.29 & & & & 0.38 \\
\hline
\end{tabular}

\section{Total soluble solids percentage (T.S.S \%):}

Total soluble solids percentage of onion was significantly affected by planting date in the first season only (Table 12). Planting on $15^{\text {th }}$ September showed the highest percentage of T.S.S, while planting on $15^{\text {th }}$ Augustus and $1^{\text {st }}$ September produced the lowest percentage in both seasons.

Total soluble solids percentage were significantly decreased as NPK rates increased in both seasons. As the control (without NPK) resulted in largest percentage of total soluble solids $\%$ in both seasons. The lowest percentages of $\mathrm{TSS} \%$ were obtained from adding higher rates of NPK in both seasons. The decrease in TSS percentage in onion bulb with the increase in nitrogen supply might be attributed to the increase in moisture contents in cells of fertilized plants. These findings are supported by those obtained by Zahran and Abdoh (1998), Al-Fraihat (2009), Nabi et al., (2010), and Shafeek et al., (2013).

Total soluble solids $\%$ was significantly increased as micronutrients foliar application rates increased in both seasons (Table 12). Spraying micronutrients twice showed the highest percentages of T.S.S, while the control treatment showed the lowest percentages, in both seasons. The results showed high percentages of 
T.S.S by spraying with micronutrients may be interpreted that $\mathrm{Fe}, \mathrm{Mn}$ and $\mathrm{Zn}$ improved photosynthesis process and consequently may enhanced carbohydrates synthesis, and such product constitute the largest part of dry weight. These findings are in harmony with those obtained by Khalil et al., (1988), Singh and Tiwari (1995), El-mansi and Sharf El-dien (2005), Manna (2013) and Rafie et al., (2017).
Results presented in Table (12) revealed that the interaction between planting date and NPK rates, and the interaction between planting date and micronutrients foliar spraying had a significant effect on $\mathrm{TSS} \%$ in the second season only, while the interaction between NPK rates, and micronutrients spraying and the triple interactions between the three factors had a significant effect in the first season only.

Table 12. Effect of planting date, NPK rates and micronutrients foliar spraying on T.S.S\% of onion grown from sets in 2013/2014 and 2014/2015 seasons.

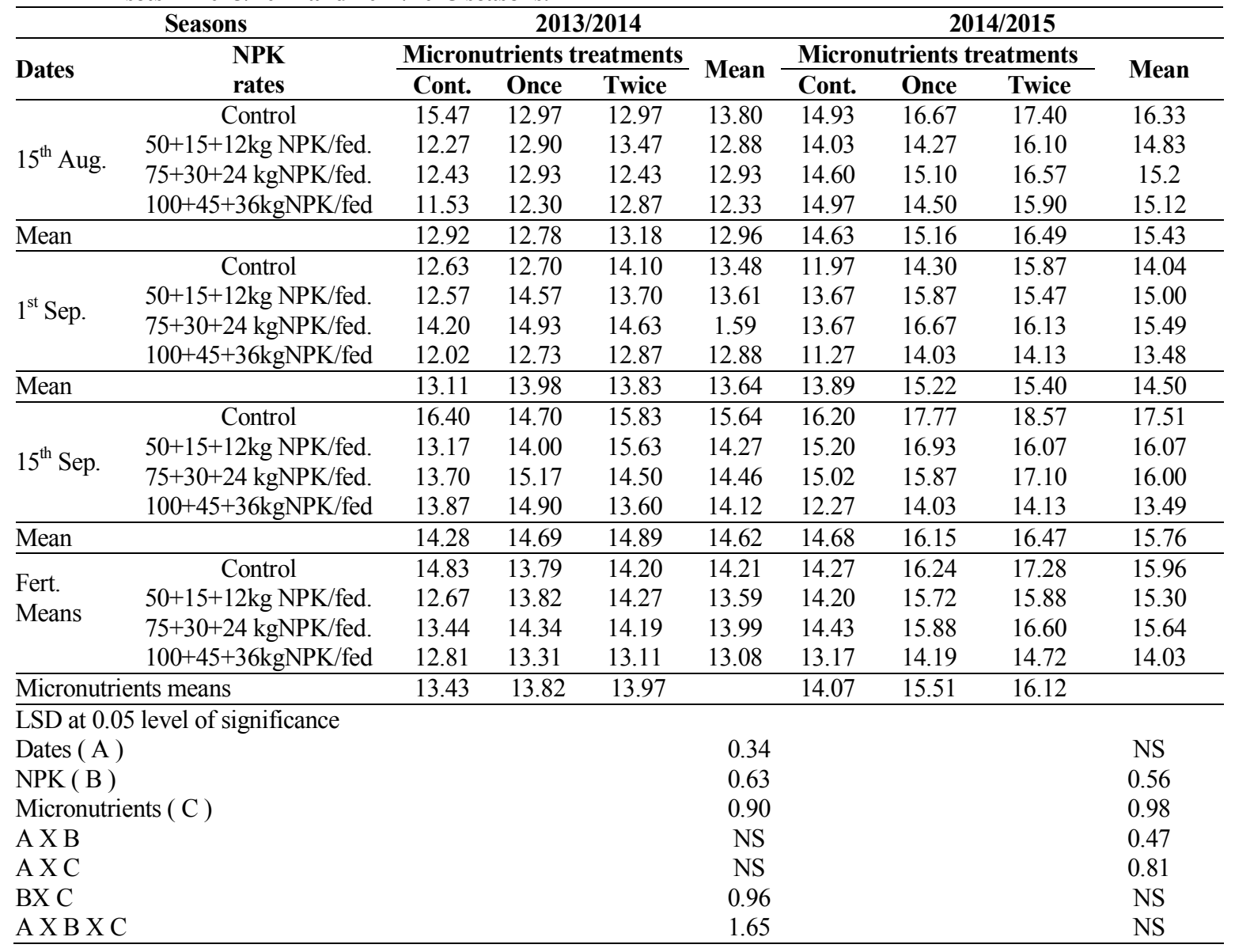

\section{Dry matter percentage (D.M. \%):}

Planting dates exerted insignificant effect on dry matter percentage in both seasons (Table 13). However, planting on $15^{\text {th }}$ August showed the highest dry matter $\%$ in both seasons, while planting on $1^{\text {st }}$ September and $15^{\text {th }}$ September produced the lowest dry matter percentage in the first and second seasons, respectively.

Dry matter percentage significantly increased as NPK rates increased in both seasons. Application of high rates of NPK $(100+45+36 \mathrm{~kg} \mathrm{NPK} /$ fed.) resulted in the highest percentage of dry matter, while the control treatment gave the lowest percentage in both seasons.

Dry matter percentage significantly increased as micronutrients foliar application rates increased in both seasons (Table 13). The highest percentages of dry matter were obtained by spraying twice with micronutrients, while the lowest dry matter percentage were obtained from the control treatment, in both seasons. The high percenages of dry matter under spraying with micronutrients may be interpreted that $\mathrm{Fe}$, $\mathrm{Mn}$ and $\mathrm{Zn}$ improved photosynthesis process and consequently may enhanced carbohydrates synthesis, and such product constitute the largest part of dry weight. Similar results were found by Manna (2013).

Results presented in Table (13) revealed that the double and triple interactions among planting date, NPK rates and micronutrients spraying had insignificant effect on dry matter percentage in the both seasons.

From the results of this experiment, It could be recommended that planting on 15th September, fertilizing with $100+45+36 \mathrm{NPK} \mathrm{kg} / \mathrm{fed}$. and spraying twice with microelements to achive maximum yield and yield components. 
Table 13. Effect of planting date, NPK rates and micronutrients foliar spraying on percentage of dry mater of onion grown from sets in 2013/2014 and 2014/2015 seasons.

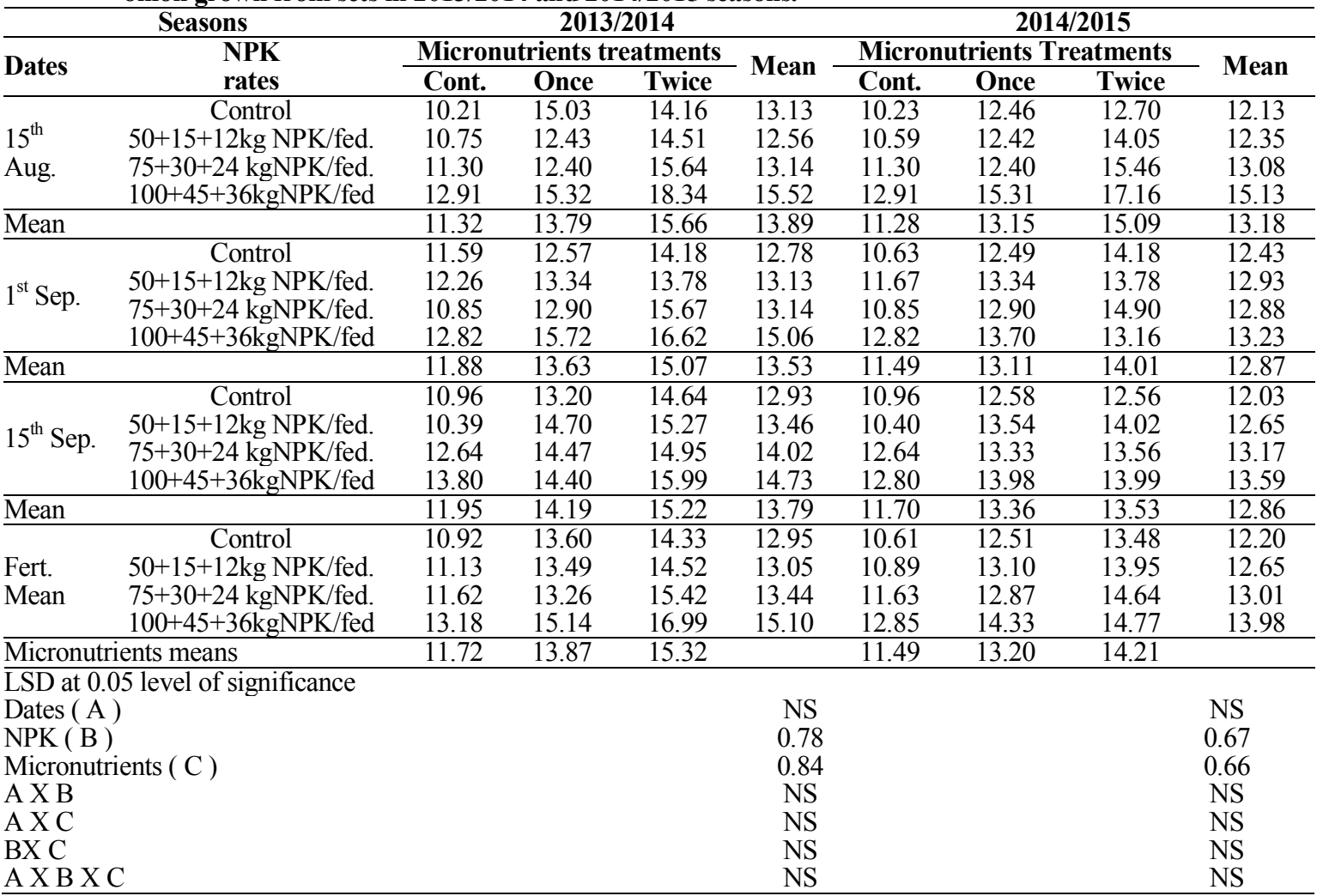

\section{REFERENCES}

A.O.A.C. (1975). "Official Methods of Analysis of the Association of Official Agriculture Chemists". Twelfth Ed. published by the Association of Official Agriculture Chemists. Washington, D.C. 832.

Abd El-Fattah, M.A.; I.A. El-Mofty; M.A. Badawi and E.M. Agwah (1983). Effect of planting date, spacing and set size on the morphological characters of onion plants. Agricultural Research Review, 61 (8): 225-249.

Abd El-Moneem K.M.H.; S.B.M. Faway;F.A.Saeed and A.I.El-Shehaby (2005). Effect of colve size and certain micronutrients on fusarium basal rot of garlic Assuit Jor.of Agri. Sci., 36(4):163-175.

Abd El-Samad, E.H., R.Kh.M. Khalifa, Z.A. Lashine and M.R. Shafeek (2011). Influence of Urea Fertilization and Foliar Application of Some Micronutrients on Growth, Yield and Bulb Quality of Onion. Australian Journal of Basic and Applied Sciences, 5(5): 96-103.

Abdissa Y., T. Tekalign and L. M. Pant (2011). Growth, bulb yield and quality of onion (Allium cepa L.) as influenced by nitrogen and phosphorus fertilization on vertisol I. growth attributes, biomass production and bulb yield . African Journal of Agricultural Research 6(14), 3252-3258.

Al-Fraihat, A. H. (2009). Effect of Different Nitrogen and Sulphur Fertilizer Levels on Growth, Yield and Quality of Onion (Allium cepa L.). Jordan Journal of Agricultural Sciences, 5(2), 155 - 166.
AL Abdulsalam A.M. and A.F. Hamaiel (2004). Effect of planting dates and compound fertilization on growth, yield and quality of Hassawi onion under Al-Hassa oasis condition. Scintific J. of King Fasisal Unvi. Basic and Applied Sci., 5(1): 65-79.

Baghdady, G.A. (2008). Growth and yield components of onion grown by sets as affected by sowing time and seed size under Assiut conditions. M.Sc. Thesis, Fac. Agric., Assiut Univ.

Barakat, M.A.; H.A. El-Katib; S.M. Gabr and E.A. Bedawy (2004). Plant growth characters of field grown onion (Allium cepa L.) as affected by nitrogen application and biofertilizers inoculation. J. Agric. Sci. Mansoura Univ., 29(1): 345-356.

Barker, A.V. and D.J. Pilbeam, (2007). Handbook of plant nutrition. $2^{\text {nd }}$ Ed., CRC Press, New York, USA.

Battal, P., (2004). Effects of some mineral nutrientson gibbrellic acid levels in maize plants. Economic Botany, 58(2): 195-203.

Brady N.C. (1990). The nature and properties and soils. $10^{\text {th }}$ edition, A.K.Ghosh.printing-Hall of India Pvt.ltd. New Delhi.p.383.

Brewester J. L. (1994). Onions and other vegetable Alliums. Ed. CAB International, Wallingford, UK, p. 236.

Bungard, R.A.; A. Wingler, J.D. Morton and M. Andrews, (1999). Ammonium can stimulate nitrate and nitrite reductase in the absence of nitrate in Clematis vitalba. Plant Cell Environ., 22: 859-866.

Chattopadhyay, S.B. and T.P. Mukhopadhyay (2004). Response of boron and molybdenum as foliar feeding on onion in tarai soil of West Bengal. Environment and Ecology, 22: 784-787. 
Christopher C. (2003). Performance of fall-sown onion cultivars using four seeding dates. Amer. Hort. Sci., 128(4): 472-478.

Dumitrecu, M. and V. Radoi (1984). The influence of planting date, set quality and planting density on onion yield quality and quantity. Amale Institutalde Cercetari Pentru Lequmiculture si floriculture, Vidra, 7: 291 - 289. [C.F. Hort. Abst. 55, 4466].

El-beheidi, M. A.; M.A.I. Khalil; H.E. Arisha and Sabreen Kh. A. Ibrahim (2004). Onion crop response to nitrogen and potassium fertilization and soil application .Hort Dept. Agric., Zgazig Unvi., Egypt Zgazig J Agri. Res., 31(5): 2123-2138.

El-Desuki, M.; A. R. Mahmoud and M. M. Hafiz (2006-a). Response of onion plants to minerals and biofertilizers application. Res. J. Agric. \& Biol. Sci., 2 (6): 292-298.

El-Desuki, M.; M. M. Abdel-Mouty and A. H. Ali (2006b). Response of onion plants to additional dose of potassium application. J. Appl. Sci. Res., 2 (9): 592-597.

El-Gamili, Aida E. and A.H. Abd El-Hadi (1996). Effect of nitrogen, phosphorus and potassium fertilizers and their interaction on the growth and yield of onion (Allium cepa L.) plant. Minufiya J. Agric. Res., 21(5): 1309-1321.

El-mansi, A.A.A. and M. S.M. Sharf El-dien (2005). Effect of foliar spray of boron and copper on dry weight, yield and storability of onion under sandy soil condition .Zagazig J.Agric. Res., 3(3): 767-791.

Esawy M., E. El-Gizaawy and L. Geries (2015). Effect of compost extract, $\mathrm{N}$-fixing bacteria and nitrogen levels applications on soil properties and onion crop. Archives of Agronomy and soil science. 61: 185-201.

Farghali, M.A; M.A. Farrag and H.A. Hussein.(1991) Effect of planting date and seed cooling on onion grown by sets. II-Harvestting time yield. Minia J. Agric.Res. \& Dev., 16(3): 831-849.

George E. B., R. L. C. Torrance; and R. Hill (2007). Effects of Nitrogen, Phosphorus, and Potassium Rates and Fertilizer Sources on Yield and Leaf Nutrient Status of Short-day Onions.HortScience 42(3): 653-660.

Ghoname A., Z.F. Fawzy, A.M. El-Bassiony; G.S. Riadand, and M.M.H.Abd El-Baky (2007). Reducing Onion Bulbs Flaking and Increasing Bulb Yield and Quality by Potassium and Calcium Application. Australian Journal of Basic and Applied Sciences, 1(gbgc 4): 610-618.

Hänsch, R. and R.R. Mendel, (2009). Physiological functions of mineral micronutrients $(\mathrm{Cu}, \mathrm{Zn}, \mathrm{Mn}$, $\mathrm{Fe}, \mathrm{Ni}, \mathrm{Mo}, \mathrm{B}, \mathrm{Cl})$. Current Opinion in Plant Biology, 12: 259-266.

Kandil A.A., A. E. Sharief and F. H. Fathalla (2013). Effect of organic and mineral fertilizers on vegetative growth, bulb yield and quality of onion cultivas. Sci. J. Crop Prod. 2(3): 91-100.

Khalil, R.M.; A.A. Midan and O.S. Abu-Grab (1988). Response of some onion cultivars to micronutrients application under Middle Delta conditions. 1. Growth, bulbing and nutritional Status. Minufiya J. Agric Res., 13(1): 228-307.
Khan A.A.; M. Zubair and Abdul Bri F. Maula (2007). Response of onion (Allium cepa L.) growth and yield to defferent levels of nitrogen and zinc in swat valley. Samad Journal of Agric., 23(4): 933-936.

Khokhar K.M. (2008). Effect of temperature and photoperiod on the incidence of bulbing and bolting in seedlings of onion cultivars of diverse origin. Journal of Horticultural Science \& biotechnology, 83:488-496

Kirkby, E.A. and V. Römheld, (2004). Micronutrients in plant physiology: functions, uptake and mobility. Proceedings No. 543, International Fertiliser Society.

Kurtz, C. and P. R. Ernani (2010). Onion yield influenced by micronutrient application. Revista Brasileira de Ciencia do Solo, 34(1):133-142.

Manna D. (2013). Growth, yield and bulb quality of onion (Alium cepa L.) in response of foliar application of boron and zinc. SAARC J. Agri., 11(1):149-153.

Marschner, H. (1995). Mineral Nutrition of Higher Plants. $2^{\text {nd }}$ Ed. Academic Press. London, UK.

May, A.; A.B. Cecilio-Filho; D.R.Q. Porto; P.F. Vargas; J.C. Barbosa (2007). Effect of onion bulb classification as a result of nitrogen and potassium levels and planting density. Horticultura-Brasileira, 25(3): 396-401.

Metwally, K. (2002). Effect of folair fertilization with micronutrients on yield and storability of onion (Allium cepa L.) and garlic (Allium Sativium 1.) plabts. The $3^{\text {rd }}$ Science Conference of Agricultural Scie., Assiut, 20-22 october :245-262.

Mohamed, G.A. and A.A. Hemida (2004). Response of Giza-6 Mohassan onion to some irrigation and nitrogen fertilization treatments. Minia J. of Agric. Res. \& Develop, 24(2): 177-190.

Morsy, M.G.; R.A. Marey; S.S. Karam and A.M.A. AboDahab (2012). Productivity and storability of onion as influenced by the different levels of NPK fertilization. J. Agric. Res. Kafer El-Sheikh Univ., 38(1) 171-187.

Mousavi S.R.; M. Galavi and Rezeaei Maryam (2013). Zinc Impotance for crop production- A Review International journalof Agronomy and plant production.Vol., 4(1)64-68.

Mozumder S.N.; M. Moniruzzaman and G.M.A. Haliim (2007). Effect of N,K, and S on the yield and storability of Transplanted onion (Allium cepa $\mathrm{L}$.) in the Hilly Region. J. of Agri. And Rural Devvelopment Gazipur, 5(1/2): 58-63.

Nabi, G.; A. Rab; S.J. Abbas; M.F. Farhatullah; F. Munsif and I. H. Shah (2010). Influence of different levels of potash on the quantity, quality and storage life of onion bulbs. Pak. J. Bot, 42(3):2151-2163.

Poornima, K.S. (2007). Effect of potassium and sulphur on yield and qualt-ity of onion and Chilli Intercrop in a Vertisol. Msc. Thesis (Agri), Uni. of Agri. Sci., Dharwad.pp. 35-81.

Rafie, M. R.; A. H. Khoshgoftarmanesh; H. Shariatmadari; A. Darabi; N. Dalir (2017) Influence of foliarapplied zinc in the form of mineral and complexed with amino acids on yield and nutritional quality of onion under field conditions. Scientia Horticulturae; 2017. 216160-168. 46. 
Rastegar, J. and M. G. Ganjehie (2009) Effects of sulphur and number of foliar application with complete micronutrient fertilizer on yield and quality of two onion cultivars. Seed and Plant Production Journal, 25-2(1): 1-13.

Rizk, Fatma A.; A.M. Shaheen, E.H. Abd El-Samad and Omaima M. Sawan (2012). Effect of Different Nitrogen plus Phosphorus and Sulphur Fertilizer Levels on Growth, Yield and Quality of Onion (Allium cepa L.). Journal of Applied Sciences Research, 8(7): 3353-3361

Sayed W. H., M. Ishtaq and S. A. Hussain (2001). Effect of different bulb size and planting dates on green leaf production of onion (Allium Cepa L.).Online Journal of Biogical Scince 1 (5):345-347.

Shafeek, M. R.; M. K. Hassan Nagwa; S. M. Singer and H. M. EL-Greadly, Nadia (2013). Effect of potassium fertilizer and foliar spraying with Etherel on plant development, yield and bulb quality of onion plants (Allium cepa L. ). Journal of Applied Sciences Research, 9(2): 1140 - 1146.

Shah, S.; C. Yajun; M. Razaq; M. Luqman; S. Fahad; U. Abdullah; and A. Sadiq (2013). Effect of potash levels and row spacing on onion yield. J. of Biology, Agriculture and Healthcare, 16: 22243208.

Shaheen, A.M., Fatma A. Rizk, A.M.M. El-Tanahy and E.H. Abd El-Samad (2011). Vegetative Growth and Chemical Parameters of Onion as Influenced by Potassium as Major and Stimufol as Minor Fertilizers. Australian Journal of Basic and Applied Sciences, 5(11): 518-525.

Shalaby, G. I.; A. I. El-Muraba; N. M. Kandeel; A. A. Gamie (1991). Effect of some cultural practices on onion bulb production grown from sets. III - Planting dates, direction of ridges and cultivars. Assiut Journal of Agricultural Sciences, 22(5): 103-121.

Sharma, P. K.; G. L.Yadav and S. Kumar (2003). Effects of methods and dates of planting of onion sets on the bulb yield of kharif onion. News Letter National Horticultural Research and Development Foundation, 23(4): 1-3.
Singh A. K. and V. Singh (2003). Influence of set size and time of planting on the growth, yield grade of Kharif onion bulbs. Annals of Agricultural Research Indian Society of Agricultural Science, 23(4): 654-658.

Singh, D.P. and R.S. Tiwari, (1995). Effect of micronutrients on growth and yield of onion (Allium cepa L.) variety Pusa Red. RecentHorticulture, 2(2): 70-77.

Sliman, Z.T.; M.A. Abdel-Hakim and A.A. Omran (1999). Response of onion to foliar application of some micronutrients. Egyptian J. of Agric. Res., 77(3): 983-993.

Snedecor, G.W. and W.G. Cochran (1973). Statistical Methods $6^{\text {th }}$ Ed. Iowa State Univ. Press, Ames., Iowa U.S.A. pp.593.

Soleymani, A. and M. H. Shahrajabian (2012). Effects of different levels of nitrogen on yield and nitrate content of four spring onion genotypes. International Journal of Agriculture and Crop Sciences. 4(4) 179-182.

Sorensen, JN and K. Grevsen (2010). Sprouting in bulb onions (Allium cepa L.) as influenced by nitrogen and water stress. J. Hort. Sci. Biotech., 76: 501-506.

Trivedi A.P. and K.N. Dhumal (2013). Effect of soil and foliar application of zinc and iron o the yield and quality of onion (Alium cepa L.) Bangaladish J. Agri. Res. 38(1):41-48.

Waller, R.A. and D.E. Duncan (1969). A bay rule for the symmetric multiple comparison problem. Amer. State Assoc. Jour. Dec., 1485-1503.

Yadave, R.L.; N.L. Sen; M.S. Fageria and R. S. Dhaka (2002). Effect of nitrogen and potassium fertilizeation on quality bulb production of onion .Haryana J. Hort. Sci. 31(4):297-298.

Yaso, I. A.; H. S. Abdel-Razek and M. A. Wahb-Allah (2007). Influence of biofertilizer and mineral nitrogen on onion growth, yield and quality under calcareous soil conditions. J. Agric. and Env. Sci. Alex. Univ. 6 (1): 248-267.

Zahran, F. A. and A. E. Abdoh (1998) Nitrogen fertilization of onion in sandy soils. Egyptian Journal of Agricultural Research, 76(3):903-911.

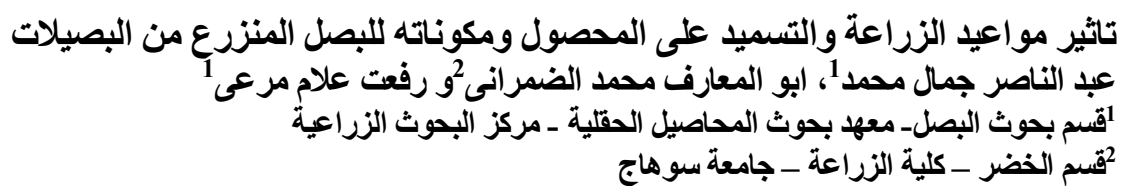

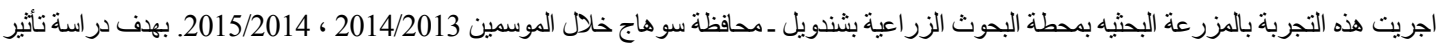

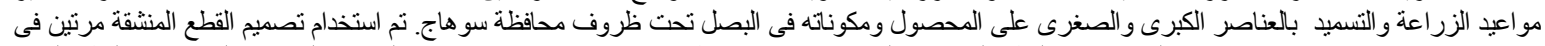

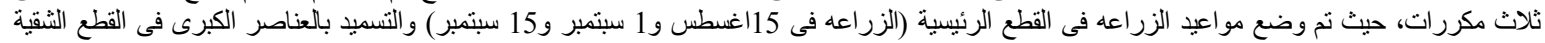

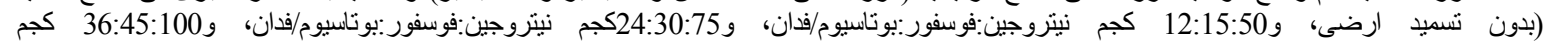

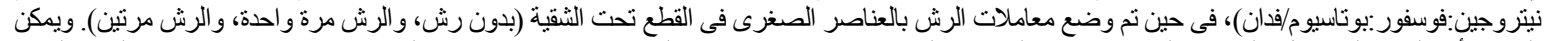

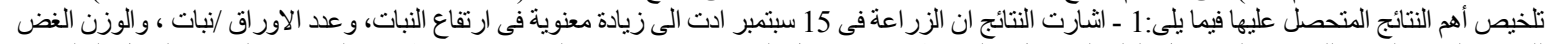

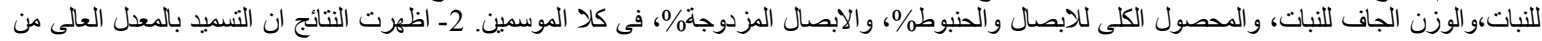

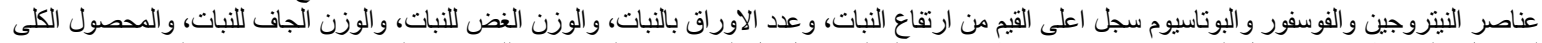

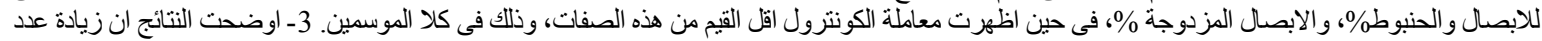

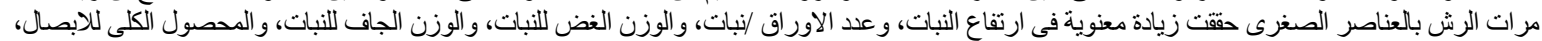

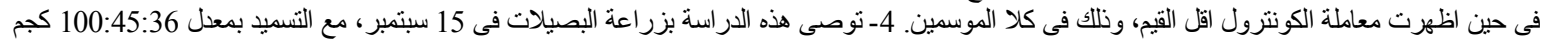

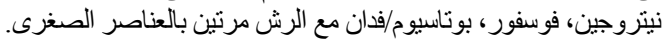

